\title{
Multi-scale modeling study of the source contributions to near-surface ozone and sulfur oxides levels over California during the ARCTAS-CARB period
}

\author{
M. Huang ${ }^{1}$, G. R. Carmichael ${ }^{1}$, S. N. Spak ${ }^{1}$, B. Adhikary ${ }^{1,2}$, S. Kulkarni ${ }^{1}$, Y. Cheng ${ }^{1}$, C. Wei ${ }^{1}$, Y. Tang ${ }^{3}$, A. D'Allura ${ }^{4}$, \\ P. O. Wennberg ${ }^{5}$, G. L. Huey ${ }^{6}$, J. E. Dibb ${ }^{7}$, J. L. Jimenez ${ }^{8}$, M. J. Cubison ${ }^{8}$, A. J. Weinheimer ${ }^{9}$, A. Kaduwela ${ }^{10}$, \\ C. Cai ${ }^{10}$, M. Wong ${ }^{11}$, R. Bradley Pierce ${ }^{12}$, J. A. Al-Saadi ${ }^{13}$, D. G. Streets ${ }^{14}$, and Q. Zhang ${ }^{14}$ \\ ${ }^{1}$ Center for Global and Regional Environmental Research, University of Iowa, Iowa City, IA, USA \\ ${ }^{2}$ School of Engineering, Kathmandu University, Dhulikhel, Nepal \\ ${ }^{3}$ Meso-scale modeling, NOAA/NCEP/EMC, W/NP2, NOAA, Camp Springs, MD, USA \\ ${ }^{4}$ ARIANET Srl, Milano, Italy \\ ${ }^{5}$ Department of Environmental Science and Engineering and Division of Geological and Planetary Sciences, California \\ Institute of Technology, Pasadena, CA, USA \\ ${ }^{6}$ School of Earth \& Atmospheric Sciences, Geogia Institute of Technology, Atlanta, GA, USA \\ ${ }^{7}$ Institute for the Study of Earth, Oceans, and Space, University of New Hampshire, Durham, NH, USA \\ ${ }^{8}$ Department of Chemistry, University of Colorado, Boulder, CO, USA \\ ${ }^{9} \mathrm{NCAR}$, Boulder, CO, USA \\ ${ }^{10}$ California Air Resource Board, Sacramento, CA, USA \\ ${ }^{11}$ Department of Geography, The University of Maryland, College Park, MD, USA \\ ${ }^{12}$ NOAA/NESDIS, Madison, WI, USA \\ ${ }^{13}$ NASA Langley Research Center, Hampton, VA, USA \\ ${ }^{14}$ Argonne National Laboratory, Argonne, IL, USA
}

Received: 22 October 2010 - Published in Atmos. Chem. Phys. Discuss.: 12 November 2010

Revised: 7 March 2011 - Accepted: 27 March 2011 - Published: 4 April 2011

\begin{abstract}
Chronic high surface ozone $\left(\mathrm{O}_{3}\right)$ levels and the increasing sulfur oxides $\left(\mathrm{SO}_{\mathrm{x}}=\mathrm{SO}_{2}+\mathrm{SO}_{4}\right)$ ambient concentrations over South Coast (SC) and other areas of California (CA) are affected by both local emissions and long-range transport. In this paper, multi-scale tracer, full-chemistry and adjoint simulations using the STEM atmospheric chemistry model are conducted to assess the contribution of local emission sourcesto $\mathrm{SC} \mathrm{O}_{3}$ and to evaluate the impacts of transported sulfur and local emissions on the SC sulfur budgetduring the ARCTAS-CARB experiment period in 2008. Sensitivity simulations quantify contributions of biogenic and fire emissions to $\mathrm{SC} \mathrm{O}_{3}$ levels. California biogenic and fire emissions contribute $3-4 \mathrm{ppb}$ to near-surface $\mathrm{O}_{3}$ over $\mathrm{SC}$, with larger contributions to other regions in CA. During a longrange transport event from Asia starting from 22 June, high
\end{abstract}

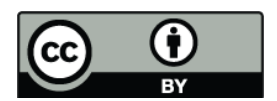

Correspondence to: M. Huang (mhuang1@engineering.uiowa.edu)
$\mathrm{SO}_{\mathrm{x}}$ levels (up to $\sim 0.7 \mathrm{ppb}$ of $\mathrm{SO}_{2}$ and $\sim 1.3 \mathrm{ppb}$ of $\mathrm{SO}_{4}$ ) is observed above $\sim 6 \mathrm{~km}$, but they did not affect CA surface air quality. The elevated $\mathrm{SO}_{\mathrm{x}}$ observed at $1-4 \mathrm{~km}$ is estimated to enhance surface $\mathrm{SO}_{\mathrm{x}}$ over $\mathrm{SC}$ by $\sim 0.25 \mathrm{ppb}$ (upper limit) on $\sim 24$ June. The near-surface $\mathrm{SO}_{\mathrm{x}}$ levels over SC during the flight week are attributed mostly to local emissions. Two anthropogenic $\mathrm{SO}_{\mathrm{x}}$ emission inventories (EIs) from the California Air Resources Board (CARB) and the US Environmental Protection Agency (EPA) are compared and applied in $60 \mathrm{~km}$ and $12 \mathrm{~km}$ chemical transport simulations, and the results are compared withobservations. The CARB EI shows improvements over the National Emission Inventory (NEI) by EPA, but generally underestimates surface $\mathrm{SC} \mathrm{SO}_{\mathrm{x}}$ by about a factor of two. Adjoint sensitivity analysis indicated that $\mathrm{SO}_{2}$ levels at 00:00 UTC (17:00 local time) at six SC surface sites were influenced by previous day maritime emissions over the ocean, the terrestrial emissions over nearby urban areas, and by transported $\mathrm{SO}_{2}$ from the north through both terrestrial and maritime areas. Overall maritime emissions contribute

Published by Copernicus Publications on behalf of the European Geosciences Union. 
$10-70 \%$ of $\mathrm{SO}_{2}$ and $20-60 \%$ fine $\mathrm{SO}_{4}$ on-shore and over the most terrestrial areas, with contributions decreasing with inland distance from the coast. Maritime emissions also modify the photochemical environment, shifting $\mathrm{O}_{3}$ production over coastal SC to more VOC-limited conditions. These suggest an important role for shipping emission controls in reducing fine particle and $\mathrm{O}_{3}$ concentrations in SC.

\section{Introduction}

In the past 20 years, California population has increased by $33 \%$ and the economy has grown rapidly (Cox et al., 2009). In the meanwhile, California has taken good efforts to reduce the emissions of most primary pollutants and the entire state has met the state and national standards for most of these pollutants except tropospheric ozone $\left(\mathrm{O}_{3}\right)$ and particulate matter (PM). Nearly all Californians live in areas that are designated as nonattainment for the state (about 99\%) and national (about 93\%) health-based $\mathrm{O}_{3}$ and/or PM standards.

$\mathrm{O}_{3}$ is an atmospheric pollutant harmful to human health and agriculture, and is also one of themost important shortlived green-house gases (GHG). The US National Ambient Air Quality Standard (NAAQS) for daily maximum 8$\mathrm{h}$ average $\mathrm{O}_{3}$ has recently been lowered to $75 \mathrm{ppb}$, and is likely to be lowered further to between $60 \mathrm{ppb}$ and $70 \mathrm{ppb}$ in future regulatory reviews of its direct impacts on human health. The California Air Resource Board (CARB) currently sets more stringent state 1-h and 8-h $\mathrm{O}_{3}$ standards at $90 \mathrm{ppb}$ and $70 \mathrm{ppb}$ to better address longstanding urban and regional $\mathrm{O}_{3}$ problems. Despite the continued precursoremission reductions, limited improvement in $\mathrm{O}_{3}$ has been achieved over the last decade. Local production from both natural and anthropogenic emission sources, together with inter-continental and in-state transport contributes to the $\mathrm{O}_{3}$ levels over both urban and rural areas.

Aerosols play an important role in the climate system causing both direct and indirect effects (IPCC report, 2007). They can be transported thousands of kilometers due to their lifetimes of about a week, and adversely affect human health and visibility. Sulfate $\left(\mathrm{SO}_{4}\right)$ is an important component of ambient aerosols, and it hasa cooling effect on climate. Sulfur compounds emitted into the atmosphere are ultimately oxidized into $\mathrm{SO}_{4}$, by a variety of oxidants such as hydroxyl radical $(\mathrm{OH})$ and hydrogen peroxide $\left(\mathrm{H}_{2} \mathrm{O}_{2}\right)$ in gas and/or liquid phases. Among various sulfur compounds, $\mathrm{SO}_{2}$ remains an important primary atmospheric pollutant. It is a highly reactive gas harmful to human respiratory system. It can be emitted from both anthropogenic and natural sources, and can be produced from oxidation of other chemicals such as hydrogen sulfide $\left(\mathrm{H}_{2} \mathrm{~S}\right)$ by $\mathrm{OH}$. $\mathrm{SO}_{2}$ emissions from anthropogenic sources are generally thought to be better known than other species such as non-methane volatile organic compounds (NMVOCs). The documented largest sources of $\mathrm{SO}_{2}$ emissions in the US are from fossil fuel combustion at power plants (66\%) and other industrial facilities (29\%) (US EPA, http://www.epa.gov/air/sulfurdioxide/). Various techniques have been used to control $\mathrm{SO}_{2}$ emissions from these large sources. However, the major $\mathrm{SO}_{2}$ emission sources over California vary with location. Unlike the continuous decreasing trend in statewide $\mathrm{NO}_{\mathrm{x}}, \mathrm{VOC}$, and $\mathrm{CO}$ emissions through the past decades, anthropogenic $\mathrm{SO}_{\mathrm{x}}$ emissions started to increase from 2005 and this trend is estimated to continue for the next 10 years. This increasing trend is mainly due to the emissions from the "other mobiles" categories, including the significant growth in shipping activities and the highsulfur fuels that ocean-going vessels typically use, especially around the coastal areas such as San Francisco (SF) and Los Angeles (LA) counties (Cox et al., 2009). Although shipping emission control regulations are in action since 2009, the $\mathrm{SO}_{2}$ levels over some South Coast (SC) surface sites are still increasing. In addition, $\mathrm{SO}_{2}$ emitted from terrestrial industrial processes, certain modes of surface transport, and area sources contribute to the $\mathrm{SO}_{\mathrm{x}}$ concentrations over southern California. Similar as for $\mathrm{O}_{3}$ and its precursors, the longrange transport of $\mathrm{SO}_{4}$ affects the California sulfur budget. Because of various health concerns, the US EPA has recently tightened the primary standard for $1-\mathrm{h} \mathrm{SO}_{2}$ to $75 \mathrm{ppb}$ and changed the $\mathrm{SO}_{2}$ monitoring requirements. The design of effective emission reduction strategies requires estimates of the factors that influence the regional background pollution levels and the local enhancements. A number of observational and modeling studies have been conducted to quantify the effects of sector emissions on near-surface $\mathrm{O}_{3}$ and $\mathrm{SO}_{\mathrm{x}}$ levels. It has been concluded that less than $40 \mathrm{ppb}$ of $\mathrm{O}_{3}$ are contributed by natural sources (Fiore et al., 2003; Wang et al., 2009; Koo et al., 2010). As for anthropogenic emissions, the effects of shipping emissions on regional air quality have been shown important since 1997 (Corbett et al., 1997) over different regions. For example, Vutukuru et al. (2008) focused their studies on the emissions from the LA - Long Beach area, where one third of the cargo containers to the US arrive (BST associates, 2007). They estimated the impacts of shipping emissions on surface 1-h and 8-h $\mathrm{O}_{3}$ to be up to $>20 \mathrm{ppb}$, and the $\mathrm{SO}_{2}$ emissions from shipping to cause a rise inon-shore $\mathrm{SO}_{2}$ concentrations by $2-4 \mathrm{ppb}$ in 2002, and is projected to grow to $8-10$ ppb by 2020 .

However, the accuracy of observational-based studies of estimating natural $\mathrm{O}_{3}$ levels relies on the representativeness of measurement sites and the methods to filter out the local anthropogenic contributions (Fiore et al., 2003), and the studies of fire impacts on $\mathrm{O}_{3}$ are mostly conducted by comparing $\mathrm{O}_{3}$ levels during fire and non-fire periods, in which way daily variations due to other factors cannot be completely excluded (Viswanathanet al., 2006; Bytnerowicz et al., 2010). Modelbased estimations are also uncertain as they are highly dependent on model resolutions, key inputs (such as emission inventories (EIs) andmeteorology conditions), chemical mechanisms, and the study periods (Pfister et al., 2008; Wang et 

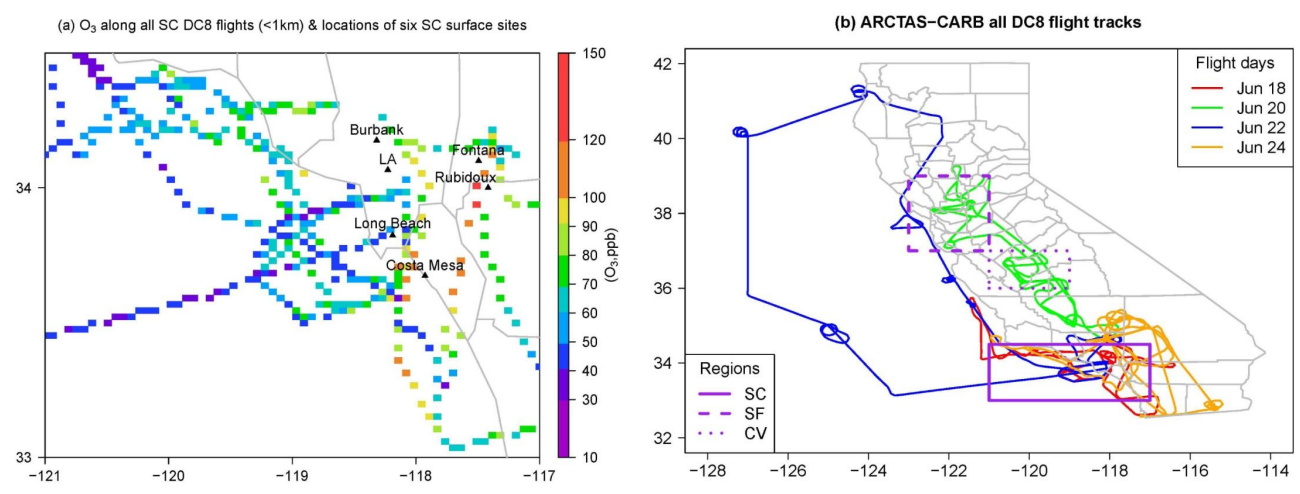

Fig. 1. (a) Observed $\mathrm{O}_{3}$ along all SC flight path below $1 \mathrm{~km}$, the locations of six SC surface sites are overlaid; (b) DC-8 flight paths on 18 , 20, 22, 24 June during ARCTAS-CARB period, and the defined study regions.

al., 2009; Koo et al., 2010). Many of these modeling studiesuse coarse grids (from $36 \mathrm{~km}$ to several degrees horizontally), and the $\mathrm{O}_{3}$ enhancement resulting from biogenic and fire sources are estimated either by tracer calculations (Pfister et al., 2008), or from simulations using purely natural emissions (Koo et al., 2010).

As one of the most important model inputs that affect the uncertainties of source contribution studies, EIs have been developed based on various data sources and assumptions, with different spatial and temporal variability. Their reliability needs to be validated. A previous field experiment, the Intercontinental Transport and Chemical Transformation of Anthropogenic Pollution (ITCT), conducted by NOAA in 2002 discovered the potential underestimation in sulfur species emissions (2010 CalNex science and implementation plan, 2008). The uncertainties imported from EIs in source contribution studies need to be quantified. By using two natural EIs (SMOKE and MEGAN), natural $\mathrm{O}_{3}$ backgrounds differed by 4 ppb in a 2002 study and were close in a 2018 case (Koo et al., 2010). Model simulations with different EIs and the comparisons with various three-dimensional observational datasets are important methods to complement the EI validation and provide better understanding of uncertainties of source contribution studies.

In this paper we estimate various source contributions to the regional background $\mathrm{O}_{3}$ levels and local enhancements of $\mathrm{SO}_{\mathrm{x}}$ by analyzing observations obtained during the California portion of the Arctic Research of the Composition of the Troposphere from Aircraft and Satellites (ARCTASCARB) field experiment period (18-24 June 2008) using the STEM regional-scale modeling system. The system used includes tracer andfull-chemistry models at two different spatial and temporal resolutions. Based on the modeled pollutant spatial patterns and the quantity of flight observational data, we mainly focus this study on California's South Coast (SC) region. We look at the near-surface $\mathrm{O}_{3}$ and $\mathrm{SO}_{\mathrm{x}}$ distributions over SC (and other regions) and identify the effects of long-range transport and local contributions. The long- range transport of $\mathrm{SO}_{\mathrm{x}}$ during a specific period is discussed in this paper $\left(\mathrm{O}_{3}\right.$ transport during this period was discussed in Huang et al. (2010)). We quantify the effects of the local emissions from natural sources (i.e., biogenic and wildfires) on $\mathrm{O}_{3}$ levels with two different EIs in two resolutions, and estimate the impacts of maritime emissions on on-shore air quality in the finer grids. We also compare results using two $\mathrm{SO}_{\mathrm{x}}$ EIs with observations and identify areas where further improvements are needed. Adjoint sensitivities are calculated and used to study the impacts of daytime and nighttime terrestrial and maritime $\mathrm{SO}_{2}$ emissions on surface $\mathrm{SC} \mathrm{SO}_{2}$ levels.

\section{Methods}

\subsection{Mission and source data}

The ARCTAS-CARB field experiment was conducted in June 2008 by the National Aeronautics and Space Administration (NASA). The NASA DC-8 aircraft platform sampled trace gas and aerosol concentrations through four scientific flights over California on 18, 20, 22 and 24 June 2008 and the flight paths are shown together in Fig. 1b. Three (18, 22, 24 June) out of the four flights took measurements over the SC area during the daytime ( 15:00-24:00 UTC (08:00 17:00 local time)). This mission had multiple scientific objectives, including improving the state emission inventories, characterizing off-shore shipping emissions, and quantifying the import of pollution from Asia (Jacob et al., 2010). Ozone was measured by the NCAR team using the Chemiluminescence method. Two $\mathrm{SO}_{2}$ measurement teams (CIT and GIT) and two $\mathrm{SO}_{4}$ measurement teams (UNH and CU - Boulder) were on board for all the flights. (http://www-air.larc. nasa.gov/cgi-bin/arcstat-c). The CIT and GIT teams both used chemical ionization mass spectroscopy (CIMS), and UNH and CU-Boulder (CUB) used Soluble Acidic Gases and Aerosol (SAGA) and Aerosol Mass Spectrometry (AMS), respectively (Weinheimer et al., 1994; Scheuer et al., 2003; 
McNaughton et al., 2007; Slusher et al., 2004; Crounse et al., 2009; Dunlea et al, 2009). These data were averaged every one minute for use in this study.

We focus this study on the SC area because it had the largest number of flight-collected air samples, although analysis was also done over the SF and the Central Valley (CV) area. The SC, SF and CV domains are defined in boxes in Fig. 1b. The latitude/longitude ranges that the three regions cover are $33^{\circ} \mathrm{N}-34.5^{\circ} \mathrm{N}, 121^{\circ} \mathrm{W}-117^{\circ} \mathrm{W} ; 37^{\circ} \mathrm{N}-$ $39^{\circ} \mathrm{N}, 123^{\circ} \mathrm{W}-121^{\circ} \mathrm{W} ; 36^{\circ} \mathrm{N}-37^{\circ} \mathrm{N}, 119^{\circ} \mathrm{W}-121^{\circ} \mathrm{W}$, respectively.

In addition to the airborne measurements, surface measurements were analyzed. The data analyzed included continuous hourly $\mathrm{SO}_{2}$ measurements with low instrument sensitivity and hourly $\mathrm{O}_{3}$ concentrations from six CARB surface sites. The locations of these sites are shown in Fig. 1a and more detailed descriptions are provided in the supplementary material (http://www.arb.ca.gov/qaweb/siteinfo.php). Sulfate aersol data used included: EPA Air Quality System (AQS) daily-averaged fine PM (diameter $0-2.5 \mu \mathrm{m}$ ) speciation data (including $\mathrm{SO}_{4}$ ) at a variety of California urban sites on 20 and 23 June (http://www.epa.gov/ttn/airs/ airsaqs/detaildata/downloadaqsdata.htm, referred as "STN" in this paper); daily-averaged fine $\mathrm{SO}_{4}$ mass from Interagency Monitoring of Protected Visual Environments (IMPROVE) sites on 20 and 23 June (http://views.cira.colostate. edu/web/DataWizard/); and weekly-averaged $\mathrm{SO}_{4}$ mass at six Californian Clean Air Status and Trends Network (CASTNET) surface sites over the remote areas (http://java.epa.gov/ castnet/index.jsp). Several CASTNET and IMPROVE sites are co-located.

\subsection{Model, meteorology and boundary conditions}

We simulated the ARCTAS - CARB period (18-24 June) usingthe Sulfur Transport and dEposition Model (STEM) - Version 2K3. The modeling system applied here included three components: (1) a hemisphere tracer model in $60 \mathrm{~km}$ polar stereographic grids (http://www.cgrer.uiowa. edu/ARCTAS/arctas-2k8.html); (2) a continental scale gasphase and aerosol chemical transport simulation in $60 \mathrm{~km}$ grids on a subset of (1) (http://www.cgrer.uiowa.edu/ ARCTAS2/arctas2-2k8.html), and (3) a regional-scale gasphase and aerosol chemical transport domain centered over California in a $12 \mathrm{~km}$ Lambert conformal conic grid, covering Nevada and part of Mexico. The SAPRC-99 chemical mechanism was used (Carter, 2000). This mechanism has been applied to many US cases and compared with several other mechanisms (Chen et al., 2010; Luecken et al., 2008). Meteorology fields for all three grids were generated by the Advanced Research Weather Research \& Forecasting Model (WRF-ARW) Version 2.2.1 (Skamarock et al., 2007) with forecast and reanalyzed meteorological inputs (Mesinger et al., 2006) for the $60 \mathrm{~km}$ and $12 \mathrm{~km}$ simulations, respectively. Different boundary conditions were used in this study for the
$60 \mathrm{~km}$ and $12 \mathrm{~km}$ simulations. In the $60 \mathrm{~km}$ base case, lateral boundary conditions (LBC) for thirty gaseous species and top boundary conditions for ten gaseous species were obtained from the archived RAQMS global model predictions. The LBCs for BC, OC, dust, sea salt and $\mathrm{SO}_{4}$ were taken from the $60 \mathrm{~km}$ STEM tracer results. Boundary conditions for the $12 \mathrm{~km}$ simulations came from the $60 \mathrm{~km}$ full-chemistry simulations. The details of the model configuration are described in Huang et al. (2010) and in Table 1.

We also used the adjoint of STEM (Sandu et al., 2005; Chai et al., 2009) to study the $\mathrm{SO}_{2}$ sensitivity with respect to receptor (the $\mathrm{SC}$ surface sites in this case) $\mathrm{SO}_{2}$ concentration during the flight week (Sect. 3.7) in the $12 \mathrm{~km}$ regional simulation. This adjoint approach has been applied in previous studies for source attribution and for data assimilation (Carmichael et al., 2008). Model forward sensitivity studies quantify the change of chemical distributions in all grids at future times in response to the perturbation of model inputs. In contrast, adjoint sensitivities represent backward in time the change of chemical distributions in those grids that influence a given receptor at a specific time.

\subsection{Emissions}

Emission inputs for each of the three modeling components differed slightly, based on respective demands for resolution and completeness. In the hemispheric tracer model, we used a bottom-up global gridded inventory developed forthe ARCTAS mission (developed by David Streets, Qiang Zhang et al., received in 2008, http://mic.greenresource.cn/arctas premission). This inventory is driven by regional-specific information on fuels and activity from various economic sectors, and includes anthropogenic, biomass and global shipping contributions. In the $60 \mathrm{~km}$ continental model, anthropogenic emissions for North America were taken from the 2001 National Emissions Estimate Version 3 (NEI 2001), an update of the 1999 US National Emissions Inventory with growth factors applied by Source Classification Code, and augmented with national inventories for Canada (2000) and Mexico (1999). The NEI 2001 includes emission around the port area, but misses the shipping emissions over the open ocean. Daily biomass burning emissions from the Real-time Air Quality Modeling System (RAQMS) (Pierce et al., 2007) were provided by the Cooperative Institute for Meteorological Satellite Studies (CIMSS). Biogenic emissions of monoterpene and isoprene were taken from twelveyear-averaged values from the Orchidee model (Lathiere et al., 2006). For the $12 \mathrm{~km}$ model the anthropogenic and biogenic emissions were re-gridded from a contemporary CARB $4 \mathrm{~km}$ emission inventory. The anthropogenic emissions outside of the CARB domain (including Mexico, states of Nevada, Washington and Idaho) were taken from NEI 2001, same as in the $60 \mathrm{~km}$ base simulation. Biomass burning emissionswere generated by the prep-chem-source model (WRF/Chem Version 3.1 users' guide, 2009), which used 
Table 1. Summary of STEM model inputs for base cases in two resolutions.

\begin{tabular}{|c|c|c|c|c|}
\hline \multirow[t]{2}{*}{ Inputs } & \multicolumn{2}{|c|}{ Source Data } & \multicolumn{2}{|c|}{ Resolutions } \\
\hline & $60 \mathrm{~km} / 18$ layers $/ 6 \mathrm{~h}$ base case & $12 \mathrm{~km} / 32$ layers $/ 1 \mathrm{~h}$ base case & $60 \mathrm{~km}$ & $12 \mathrm{~km}$ \\
\hline Meteorology, WRF 2.2.1 & GFS + one time step SST & NARR + daily SST & $6 \mathrm{~h}, 1^{\circ} \times 1^{\circ}$ & $3 \mathrm{~h}, 36 \mathrm{~km}$ \\
\hline Ozone column, required by the TUV model & \multicolumn{2}{|c|}{$\begin{array}{c}\text { Measured by Ozone Mapping Spectrometer (OMI) instrument on board } \\
\text { the NASA Aura spacecraft, daily }\end{array}$} & \multicolumn{2}{|c|}{$1^{\circ} \times 1^{\circ}, 1$ day } \\
\hline Anthropogenic Emissions (point and mobile) & NEI 2001, weekday varied from weekends & $\begin{array}{l}\text { CARB 2005, projected from 2002, daily varied. } \\
\text { Out of CARB domain filled with NEI } 2001\end{array}$ & $1^{\circ} \times 1^{\circ}, 1 \mathrm{~h}$ & $4 \mathrm{~km} \times 4 \mathrm{~km}, 1 \mathrm{~h}$ \\
\hline Biogenic Emissions & Orchidee & CARB 2005 projected from 2002, daily varied & $1^{\circ} \times 1^{\circ}$, monthly averaged & $4 \mathrm{~km} \times 4 \mathrm{~km}, 1 \mathrm{~h}$ \\
\hline Biomass burning Emissions & RAQMS real time & $\begin{array}{l}\text { MODIS-detected hot spots, processed by } \\
\text { prep-chem-source model; } \\
\text { mass-conserved normalization }\end{array}$ & $1^{\circ} \times 1^{\circ}, 12 \mathrm{~h}$ & $1 \mathrm{~km} \times 1 \mathrm{~km}, 24 \mathrm{~h}$ \\
\hline Top and Lateral Boundary Conditions & $\begin{array}{l}\text { RAQMS real time (gases) + STEM tracer } \\
\text { (several aerosols) }\end{array}$ & STEM $60 \mathrm{~km}$ base case & $\begin{array}{l}2^{\circ} \times 2^{\circ}, 6 \mathrm{~h} \text { and } \\
60 \mathrm{~km} \times 60 \mathrm{~km}, 6 \mathrm{~h}\end{array}$ & $\begin{array}{l}60 \mathrm{~km} \times 60 \mathrm{~km}, \\
18 \text { layers, } 6 \mathrm{~h}\end{array}$ \\
\hline
\end{tabular}

Acronyms:

GFS: Global Forecast Systen

NARR: North American Regional Reanalysis

MODIS: Moderate Resolution Imaging Spectroradiometer

TUV: Tropospheric Ultraviolet and Visible (TUV) Radiation Model

Other acronyms are defined in text.

MODIS - detected point fire information at $1 \mathrm{~km}$ ground resolution (Giglio et al., 2003; Davies et al., 2009) and was adjusted at each time step to match total emissions rates from RAQMS. $\mathrm{H}_{2} \mathrm{~S}$ and dimethyl sulfide (DMS) emissions were not included in these cases.

\section{Results and discussions}

\subsection{General conditions and $\mathrm{O}_{3}$ levels in base cases}

The California summer climate in 2008 was hot and dry, influenced by the Pacific high pressure system. Wildfire events broke out on 21 June at various locations over both northern and southern California. On 18-20 June, fires were detected along the California-Mexico border.

The $12 \mathrm{~km}$ average WRF-modeled $10 \mathrm{~m}$ winds at multiple times $(00: 00,06: 00,12: 00$ and 18:00 UTC - 17:00, 23:00, 05:00, 11:00 local time, respectively) over California during the experiment week are shown in Fig. 2. The northwesterly winds along the coast and through the Central Valley, together with the sea-land breezes, determined the regional transport of pollutants during this period. The wind vectors are overlaid on the WRF-predicted mixing layer height (PBLHT). The PBLHT over the ocean stayed below $\sim 600 \mathrm{~m}$, while the PBLHT over parts of the SC terrestrial areas reached up to $\sim 1500 \mathrm{~m}$ during daytime. These are consistent with the vertical structures of short-lived chemicals observed by the aircraft measurements (shown in Fig. 7, to be discussed).

The observed $\mathrm{O}_{3}$ concentrations along all DC8 flights (Sect 2.1 and Fig. 1) below $1000 \mathrm{~m}$ are shown in Fig. 1a and 3e horizontally and vertically, respectively. Observed $\mathrm{O}_{3}$ ranged from less than $40 \mathrm{ppb}$ to $\sim 120 \mathrm{ppb}$ with large variability. The highest $\mathrm{O}_{3}$ levels ( $>120 \mathrm{ppb}$ ) were found around
Riverside. The $\mathrm{O}_{3}$ levels over the ocean were typically below $80 \mathrm{ppb}$.

The modeled $\mathrm{O}_{3}$ concentrations from the $12 \mathrm{~km}$ simulations are shown in Fig. 3a and b, for the 15:00-24:00 UTCaveraged $\mathrm{O}_{3}$, and for the daily averaged maximum $\mathrm{O}_{3}$, respectively. The predicted $\mathrm{O}_{3}$ concentrations over the Central Valley and southern California are over $70 \mathrm{ppb}$ during the flight times. The averaged $\mathrm{O}_{3}$ levels during the flight times over northern California, southern California urban areas are 5-10 ppb lower. The predicted average daily maximum $\mathrm{O}_{3}$ levels occur in the Central Valley and a large part of southern California ( $>90 \mathrm{ppb}$ ).

Finer grid simulations are usually expected to better capture local features. However, coarser grids (in this study, the $60 \mathrm{~km}$ ) simulations (typically used in global models and in forecast-mode regional model simulations) with different model inputs are also valuable to evaluate the uncertainties of model sensitivity to sector emissions, which will be described in detail in Sect. 3.2. The base case simulations are shown in this section first. The modeled $\mathrm{O}_{3}$ concentrations from the $60 \mathrm{~km}$ simulations are presented in Fig. $3 \mathrm{c}$ and $\mathrm{d}$, for the averaged 15:00-24:00 UTC $\mathrm{O}_{3}$, and for the averaged daily maximum $\mathrm{O}_{3}$, respectively. Overall the $60 \mathrm{~km}$ simulations show similar spatial patterns over CA compared with the $12 \mathrm{~km}$ results, but lower $\mathrm{O}_{3}$ concentrations over the Central Valley and southern California.

Figure $3 \mathrm{e}$ compares the predicted $\mathrm{O}_{3}$ for the two model resolutions with all flight observations below $1000 \mathrm{~m}$ vertically. The $12 \mathrm{~km}$ simulations captured the observed variability fairly well, with the correlation of 0.62 . It generally overpredicted the $\mathrm{O}_{3}$ concentrations, but captured the higher observed concentrations ( $>75 \%$ quantile, mostly over terrestrial regions) better, with mean bias $11.6 \mathrm{ppb}$ and root mean square error $13.9 \mathrm{ppb}$. The $60 \mathrm{~km}$ simulations showed less 

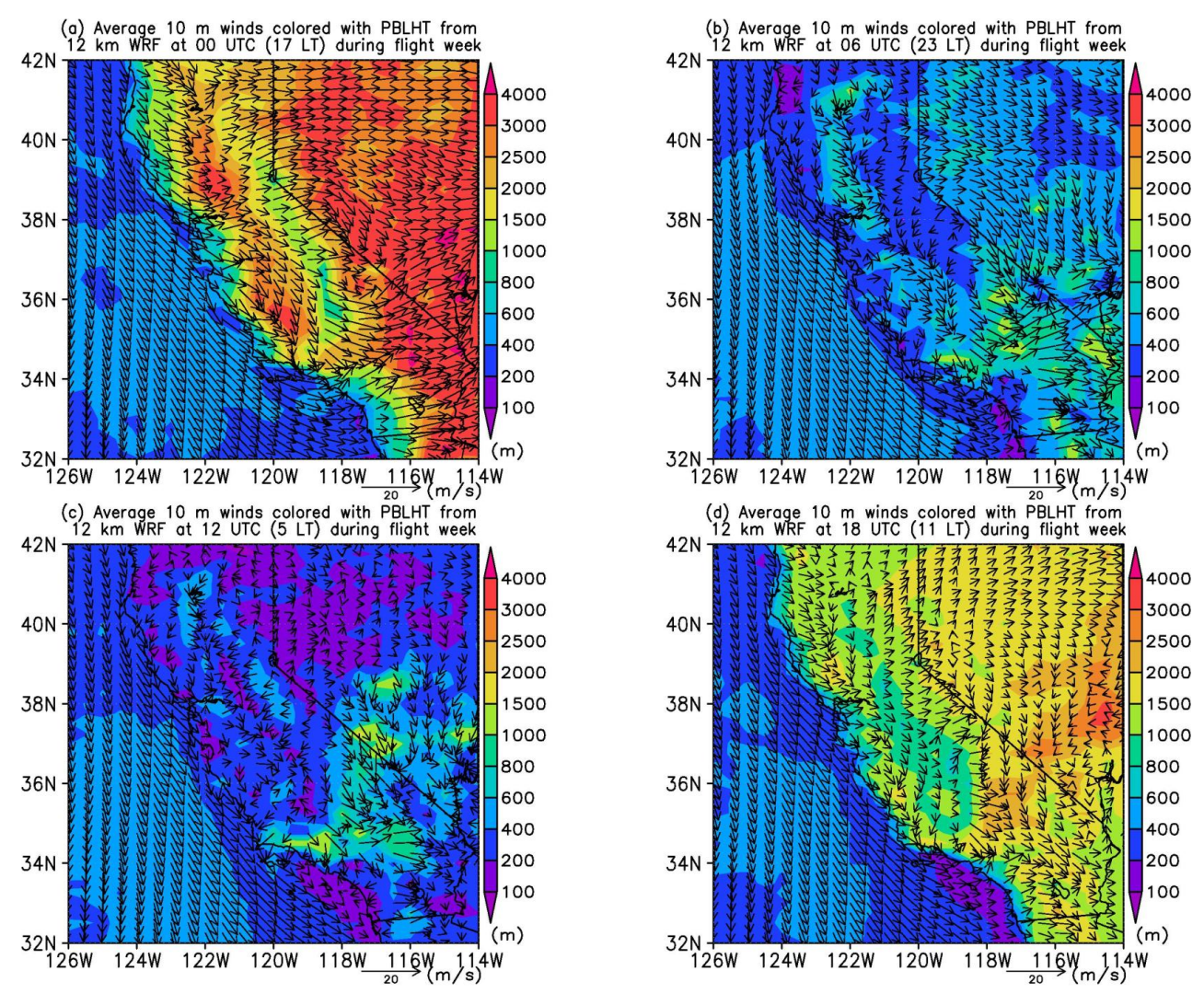

Fig. 2. Weekly-average $12 \mathrm{~km}$ WRF $10 \mathrm{~m}$ wind fields, at (a) 00:00 UTC (17:00 local time) (b) 06:00 UTC (23:00 local time) (c) 12:00 UTC (05:00 local time) (d) 18:00 UTC (11:00 local time), overlaid on $12 \mathrm{~km}$ WRF-predicted mixing layer height (m).

vertical variability, but similar correlation with observations $(r=0.58)$ as the $12 \mathrm{~km}$ simulations. Its extent of overpredition of $\mathrm{O}_{3}$ was lower than the $12 \mathrm{~km}$ case, but the simulations for the higher-observed concentrations ( $>75 \%$ quantile) showed higher biases, with mean bias of $15.9 \mathrm{ppb}$ and root mean square error of $19.8 \mathrm{ppb}$.

Figure $3 \mathrm{f}$ compares the observed and modeled $\mathrm{O}_{3}$ time series averaged over the six CARB surface sites (Fig. 1a) during the flight week. No significant weekday-weekend variations (21 and 22 June are Sat. and Sun.) are found. The $12 \mathrm{~km}$ simulation results were well correlatedwith the observations $(r=0.73)$, and captured the daytime variations fairly well. Nighttime $\mathrm{O}_{3}$ concentrations were over-predicted by $10-30 \mathrm{ppb}$, due to the under prediction of nighttime $\mathrm{NO}_{\mathrm{x}}$ and uncertainties in the transport of upwind $\mathrm{O}_{3}$ concentrations. The $60 \mathrm{~km}$ results showed lower correlations $(r=0.6)$ and weaker diurnal variations, with higher overpredictions during the night time. It is harder for the coarser grids to capture the night time titration processes and the transport of background $\mathrm{O}_{3}$ from the upwind locations.

\subsection{Influences of natural source emissions on $\mathrm{SC} \mathrm{O}_{3}$}

In order to quantify the impacts of natural emission sources on $\mathrm{SC} \mathrm{O}_{3}$ levels, we conducted two sensitivity simulations in the $12 \mathrm{~km}$ grids. We turned off the biogenic (isoprene and monoterpene) emissions and wildfire emissions for the two cases, respectively, and analyzed the changes of $\mathrm{O}_{3}$ between the base and each of the sensitivity cases.

Figure $4 \mathrm{a}$ shows the 24-h average isoprene and monoterpene emissions from the CARB EI. Their emissions are highly related to the land use type (not shown) and vary over California. Isoprene and monoterpene emission rates are the highest over northern California regions covered by evergreens, and account for 40-60\% of total NMVOC emissions over those regions. In contrast, in the Central Valley and south coast urban areas, the emission rates are more than 20 times lower, accounting for less than $2 \%$ of the total NMVOC emissions (not shown).

The differences of flight time (15:00-24:00 UTC) and daily maximum surface $\mathrm{O}_{3}$ concentrations during the flight week between the base and no-biogenic emission cases are shown in Fig. 4c, and e, respectively. The largest $\mathrm{O}_{3}$ decreasesis found over northern California and the $\mathrm{CV}$, with the flight time $\mathrm{O}_{3}$ changes up to $6 \mathrm{ppb}$ and the average daily maximum changes from 6 to $12 \mathrm{ppb}$. In contrast, the $\mathrm{O}_{3}$ changes over the SC area are shown smaller, between 2 and $4 \mathrm{ppb}$.

The impacts of fires on 24-h average surface CO during the flight week are shown in Fig. $4 \mathrm{~b}$. The highest differences 

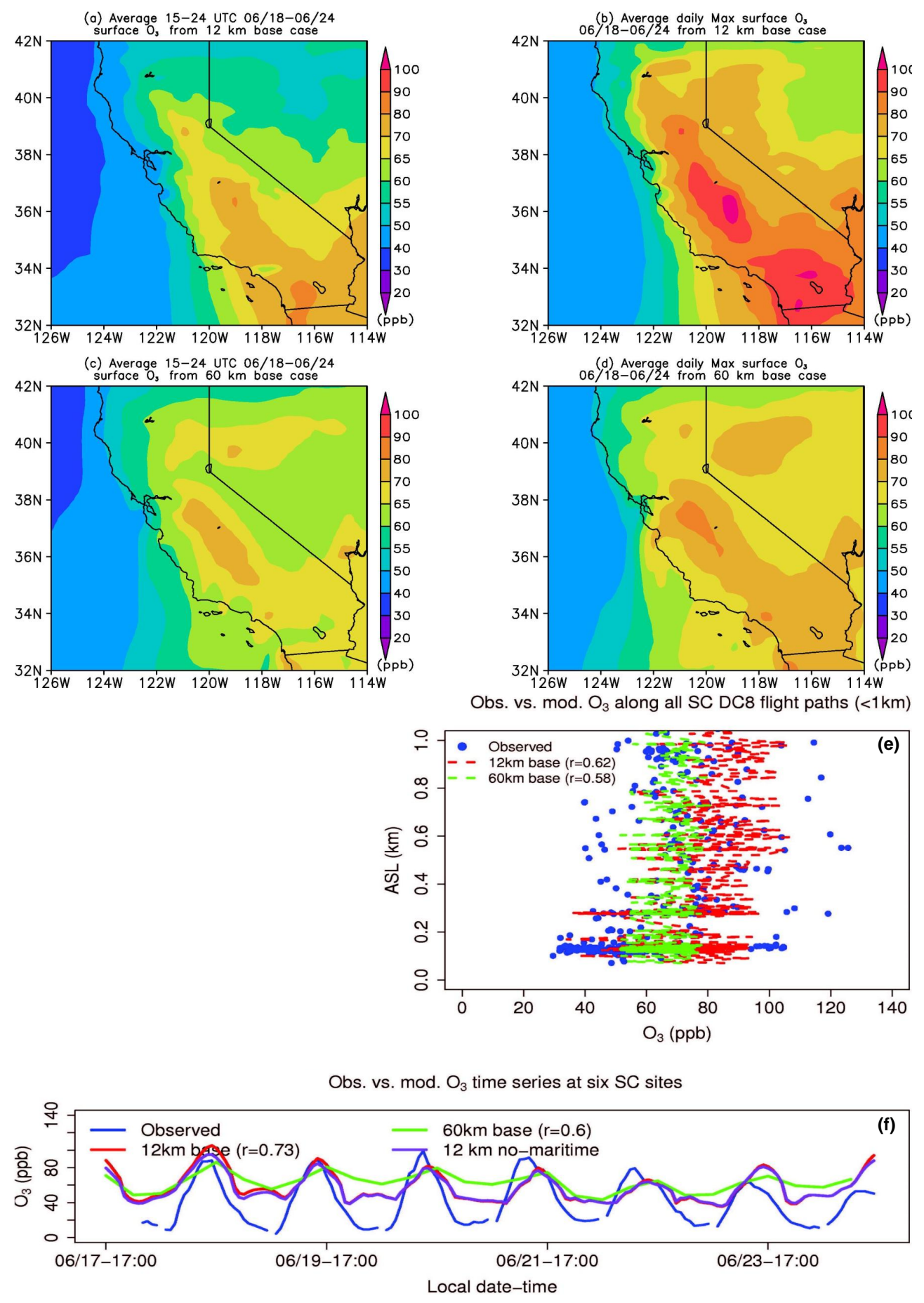

Fig. 3. (a-b) $12 \mathrm{~km}$ and (c-d) $60 \mathrm{~km}$ modeled (a, c) average 15:00-24:00 UTC (08:00-17:00 local time) and (b, d) daily maximum surface $\mathrm{O}_{3}$; (e) Observed and modeled $\mathrm{O}_{3}$ vertical profiles along all SC flight paths below $1 \mathrm{~km}$; (f) Observed and modeled (60 km base, $12 \mathrm{~km}$ base and no-maritime emissions cases) $\mathrm{O}_{3}$ time series at six $\mathrm{SC}$ surface sites.

( $>100 \mathrm{ppb}$ ) due to California fires occur over northern California, where the wildfires were most intense and durations the longest. Fire locations with changes in $\mathrm{CO}$ of 400 $800 \mathrm{ppb}$ are shown in northern California and the Monterey Bay areas, and the fire impacts on $\mathrm{CO}$ extend to the SC coastal areas (20-50 ppb of delta CO between base and nofire cases). Analysis of the impacts from wildfires in North Asia and Europe, and South Asia and Africa using the tracer model indicate that the fires thatoccurred outside of the North America had negligible impacts on surface SC air quality 
Table 2. Modeled $\mathrm{O}_{3}$ sensitivity along flight paths below $1 \mathrm{~km}$ from both resolution cases.

\begin{tabular}{|c|c|c|c|c|c|c|}
\hline \multirow{2}{*}{$\begin{array}{l}12 \mathrm{~km} \\
\text { Flight day }\end{array}$} & \multicolumn{3}{|r|}{ Biogenic } & \multicolumn{3}{|r|}{ Fire } \\
\hline & Mean $(\%)$ & $\operatorname{Max}(\%)$ & $\begin{array}{l}\text { Number of points with sensitivity } \\
>10 \% / \text { total number of points (\%) }\end{array}$ & Mean $(\%)$ & $\operatorname{Max}(\%)$ & $\begin{array}{l}\text { Number of points with sensitivity } \\
>10 \% / \text { total number of points }(\%)\end{array}$ \\
\hline 18 June SC & 1.36 & 4.98 & 0 & 0.28 & 0.65 & 0 \\
\hline 20 June SC & I & 1 & I & I & I & I \\
\hline 22 June SC & 1.64 & 3.73 & 0 & 2.81 & 13.72 & 5 \\
\hline 24 June SC & 5.04 & 8.87 & 0 & 14.47 & 26.55 & 62.50 \\
\hline all SC & 2.3 & 8.87 & 0 & 4.26 & 26.55 & 16.14 \\
\hline all CA & 2.84 & 19.87 & 1.98 & 4.78 & 30.2 & 19.85 \\
\hline $60 \mathrm{~km}$ & \multicolumn{3}{|r|}{ Biogenic } & \multicolumn{3}{|r|}{ Fire } \\
\hline Flight day & Mean $(\%)$ & $\operatorname{Max}(\%)$ & $\begin{array}{l}\text { Number of points with sensitivity } \\
>10 \% / \text { total number of points }(\%)\end{array}$ & Mean $(\%)$ & $\operatorname{Max}(\%)$ & $\begin{array}{l}\text { Number of points with sensitivity } \\
>10 \% / \text { total number of points }(\%)\end{array}$ \\
\hline 18 June SC & 6.04 & 26.5 & 15.7 & 3.19 & 25.65 & 5.38 \\
\hline 20 June SC & I & I & I & I & 1 & I \\
\hline 22 June SC & 1.63 & 5.57 & 0 & 2.05 & 6.2 & 0 \\
\hline 24 June SC & 1.48 & 3.92 & 0 & 5.43 & 17.04 & 15.38 \\
\hline all SC & 3.8 & 26.5 & 7.85 & 3.41 & 25.65 & 6.28 \\
\hline all CA & 5 & 26.78 & 9 & 5.34 & 26.1 & 13 \\
\hline
\end{tabular}

( $<5 \%$ below $\sim 1.5 \mathrm{~km}$, not shown) during this period. The differences of flight time (15:00-24:00 UTC) and daily maximum surface $\mathrm{O}_{3}$ during the flight week between the base and no-fire emission cases are shown in Fig. $4 \mathrm{~d}$ and f, respectively. The largest changes in averaged daily maximum $\mathrm{O}_{3}$ occur over the northern part of the California-Nevada border $(9-15 \mathrm{ppb})$. Negative $\mathrm{O}_{3}$ changes can be found around the fire locations, indicating the strong influences of aerosol emissions from fires. Over the SC area, the fire impacts on the average surface maximum and flight time $\mathrm{O}_{3}$ are $\sim 1-$ $3 \mathrm{ppb}$.

To better understand the impact of biogenic and fire emissions on $\mathrm{O}_{3}$ concentrations within the boundary layer, we calculated the model sensitivity for each of the one-minute flight data below $1000 \mathrm{~m}$, using Eq. (1).

Sensitivity $(\%)=\frac{\mid \text { base case } \mathrm{O}_{3}-\text { sensitivity case } \mathrm{O}_{3} \mid}{\text { base case } \mathrm{O}_{3}} \times 100 \%$

The model sensitivities are plotted in Fig. 5a and b. The sensitivities in both cases are below $\sim 30 \%, \mathrm{O}_{3}$ over the $\mathrm{CV}$ area was largely affected by biogenic emissions. The $\mathrm{O}_{3} \mathrm{lev}$ els over northern $\mathrm{CV}$, the $\mathrm{SF}$ coast, and the central coast were highly impacted by the fire emissions.

The mean and maximum sensitivity for each flight day in $\mathrm{SC}$ are summarized in Table 2. The mean $12 \mathrm{~km}$ model results show that biogenic and fire emissions contributed $2.3 \%$ and $4.3 \%$, respectively, to near surface $\mathrm{O}_{3}$ over SC (with maximum values reaching contributions of $8.9 \%$ and $26.6 \%$ for each of these sources, respectively). The contributions of biogenic and fire emissions were higher in regions outside of SC.
To help assess the uncertainties in estimating the role of natural emissions, no-biogenic and no-fire emission sensitivity simulations were also conducted in the $60 \mathrm{~km}$ grid domain. The 24-h average Orchidee EI (Fig. 6a) shows a smoother but similar spatial pattern as the $12 \mathrm{~km}$ CARB estimates, with the maximum emission rates over northern $\mathrm{Cal}-$ ifornia, lower than the CARB EI. Moreover, the magnitudes are much lower than the CARB EI along the coastal areas and higher over southeastern California. Delta $\mathrm{O}_{3}$ between the $60 \mathrm{~km}$ base and no-biogenic emission cases are shown in Fig. $6 \mathrm{c}$ and e. The changes in average daily maximum $\mathrm{O}_{3}$ are of similar magnitude as in the $12 \mathrm{~km}$ grids over northern California and $\mathrm{CV}$, but are 5-8 ppb over the SC area, higher than the changes in the $12 \mathrm{~km}$ grids. The $\mathrm{O}_{3}$ changes during flight times (15:00-24:00 UTC) also differ from the $12 \mathrm{~km}$ cases, with higher magnitudes overall (changes over the SC of 5$6 \mathrm{ppb}$ ). The different $\mathrm{O}_{3}$ changes over $\mathrm{SC}$ between the two resolution cases are not only due to the emission differences within California, but also reflect the impacts of model resolution on flow fields, mixing layer height, and the contributions from the Nevada and Mexico biogenic emissions, which the CARB EI does not include.

The differences of daily maximum surface $\mathrm{O}_{3}$ during the flight week between the base and no-fire emission cases in $60 \mathrm{~km}$ grids are shown in Fig. 6f. Same as in the $12 \mathrm{~km}$ cases, the highest changes occur over the north part of CaliforniaNevada border (9-15 ppb). Figure 6d shows higher flight time average $\mathrm{O}_{3}$ changes than in the $12 \mathrm{~km}$ cases (approximately doubled magnitudes over most areas). Negative $\mathrm{O}_{3}$ changes are not found over California because the coarse resolution smooths the intensity of fire emissions, as the $\mathrm{CO}$ 

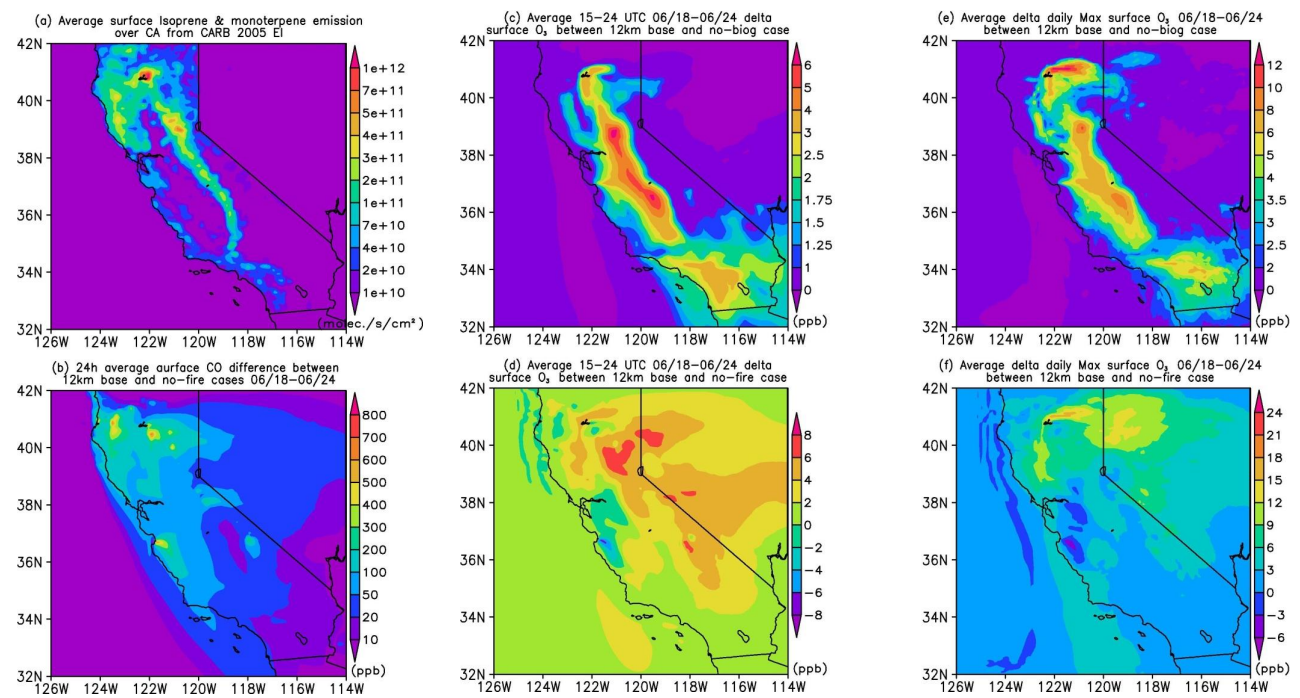

Fig. 4. (a) Average surface isoprene and monoterpene emissions from CARB EI (b) 24 h-average differences of CO between base and no-fire cases in $12 \mathrm{~km}$ grids; Surface $\mathrm{O}_{3}$ differences between (c, e) base and no-biogenic cases and (d, f) base and no-fire cases of (c-d) averaged 15:00-24:00 UTC (08:00-17:00 local time) and (e-f) average daily maximum $\mathrm{O}_{3}$ in $12 \mathrm{~km}$ grids.
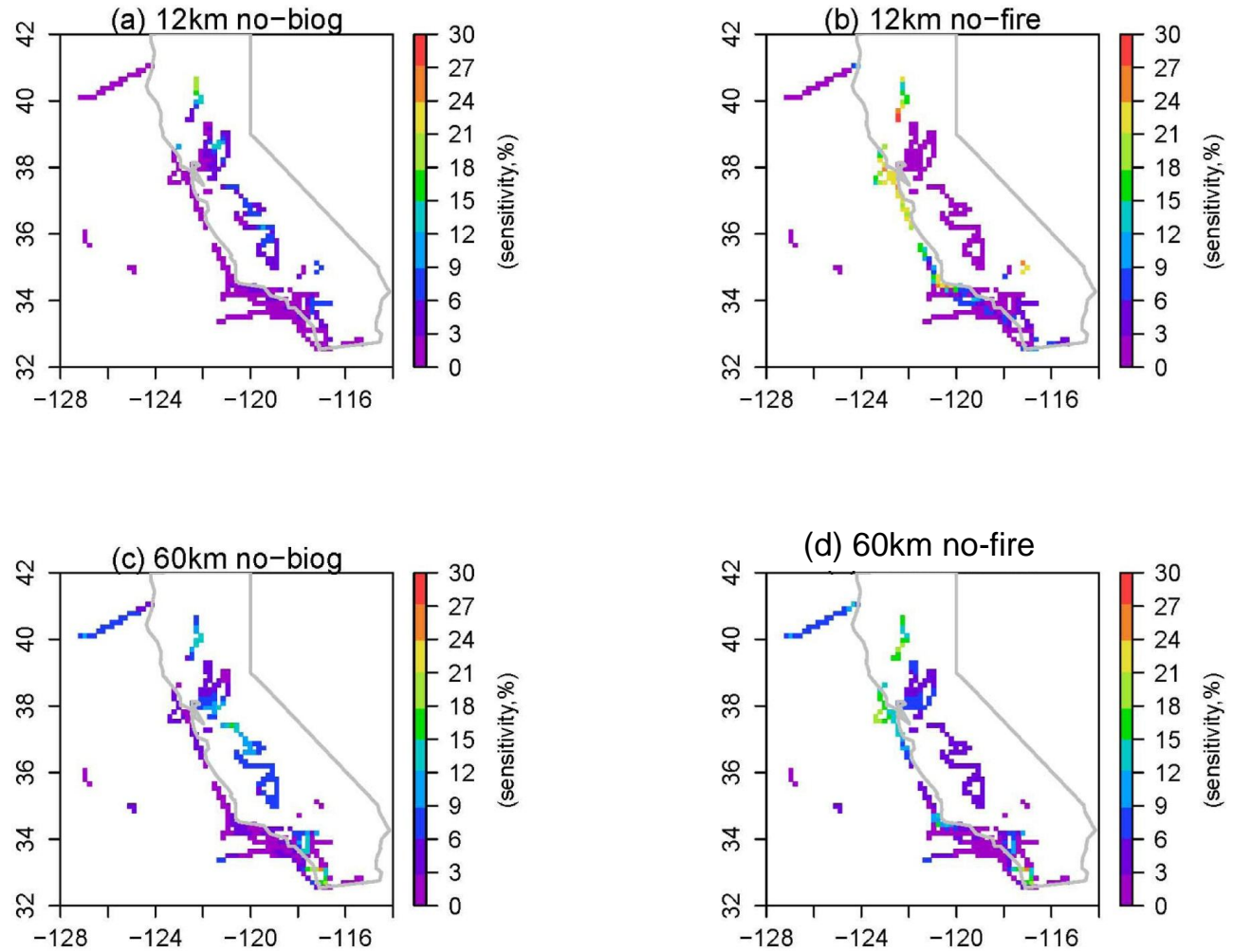

(d) $60 \mathrm{~km}$ no-fire

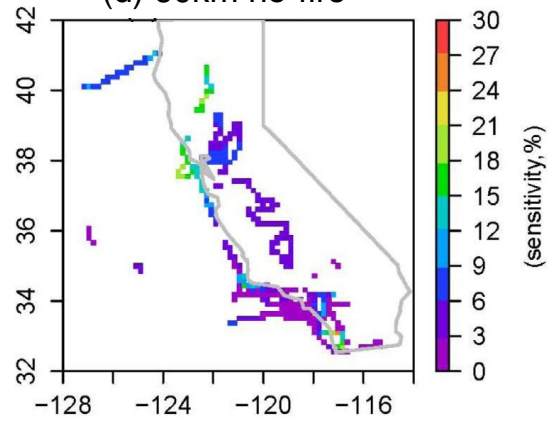

Fig. 5. Model $\mathrm{O}_{3}$ sensitivity for $(\mathbf{a}, \mathbf{c})$ no-biogenic case (b, d) no-fire case from the $12 \mathrm{~km}(\mathbf{a}-\mathbf{b})$ and $60 \mathrm{~km}(\mathbf{c}-\mathbf{d})$ cases.

differences in Fig. 6b show. Over the SC area, the fire impacts on the average surface maximum and flight time $\mathrm{O}_{3}$ are less than $\sim 4 \mathrm{ppb}$.

The model sensitivity along all SC flight paths below 1000 $\mathrm{m}$ in $60 \mathrm{~km}$ grids are shown in Fig. $5 \mathrm{c}$, $\mathrm{d}$ and Table 2. The
$60 \mathrm{~km}$ simulations show high sensitivity of $\mathrm{O}_{3}$ to biogenic emissions along the southern California-Mexico border. Due to the Mexico biogenic emissions, the $60 \mathrm{~km}$ differences between base and no-biogenic emissions cases are higher at SC. Stronger model sensitivity to fire emissions is found over that 
region and less strong sensitivity to fire emissions can be seen along the coastal SC areas, indicating the effects of model resolution and fire locations.

The sensitivity studies conducted in two resolutions suggest that fire and biogenic emissions play more important roles in $\mathrm{O}_{3}$ production over areas outside of $\mathrm{SC}$ during the ARCTAS-CARB period. The different model configurations indicate a 3-4 ppb uncertainty due to various factors (such as resolution, EIs, emission injection heights, meteorology fields).

\section{3 $\mathrm{SO}_{\mathrm{x}}$ spatial distributions and model-observation comparisons}

Observed and modeled $\mathrm{SO}_{\mathrm{x}}$ spatial-temporal distributions over SC are discussed in this section. The $60 \mathrm{~km}$ domain was used in forecast mode in support of the ARCTAS experiment. The evaluation of the $60 \mathrm{~km}$ results found significant negative biases. This motivated the $12 \mathrm{~km}$ simulations designed in the post-analysis stage to assess the impacts of model resolution, EI and other factors on model prediction skills.

The model-predicted 24-h surface average total sulfur levels during the experiment week from the $12 \mathrm{~km}$ and $60 \mathrm{~km}$ simulationsare shown in Fig. 7a and c. The corresponding $\mathrm{SO}_{2}$ contributions to total sulfur $\left(\mathrm{SO}_{2}+\mathrm{SO}_{4}, \mathrm{SO}_{4}\right.$ was converted to ppb) are also shown in Fig. 7b, d. Elevated sulfur levels can be seen over SC, SF and Fresno in CV, as well as around the California - Nevada border and the west California - Mexico border, due to the fresh emissions $\left(\mathrm{SO}_{2} \%\right.$ $>60 \%$ ). The sulfur levels at these areas from the $60 \mathrm{~km}$ simulations are generally lower than the $12 \mathrm{~km}$ case, especially over the SC area. Due to the lack of the shipping emissions in the NEI 2001, the sulfur levels over the ocean are low in the $60 \mathrm{~km}$ case, except the near-shore areas of the central coast. In contrast, the $12 \mathrm{~km}$ base case shows more detailed local features over land and the gradients along ship tracks in the ocean.

Figure $7 \mathrm{e}$ and $\mathrm{f}$ shows the observed total sulfur along all DC-8 flights (below $1 \mathrm{~km}$ a.s.l.), together with the $\mathrm{SO}_{2} \%$ in the SC area. The observed total sulfur is the sum of averaged $\mathrm{SO}_{2}$ and $\mathrm{SO}_{4}$ (units are converted to $\mathrm{ppb}$ ) measured by different teams. The $\mathrm{SO}_{2} \%$ is the ratio of the averaged $\mathrm{SO}_{2}$ concentrations measured by the two teams over the total sulfur concentrations. Similar to the model simulations, fresh $\mathrm{SO}_{2}\left(\mathrm{SO}_{2} \%>60 \%\right)$ and higher sulfur levels were observed within the $\mathrm{SC}$ domain. Over $\mathrm{SC}, \mathrm{SO}_{\mathrm{x}}$ levels were higher at on-shore port areas, such as around Long Beach (up to 5$12 \mathrm{ppb}$ ), than over the inland areas (below $\sim 0.5-2 \mathrm{ppb}$ ).

The modeled total sulfur concentrations are compared with observations along all SC DC-8 flights (below $5 \mathrm{~km}$ a.s.1.), and are shown as vertical profiles in Fig. $7 \mathrm{i}$. The steps used to combine the data from different measurement teams to create average observed values are described here. First, we calculated $\mathrm{SO}_{2}$ and $\mathrm{SO}_{4}$ profiles separately. As there were two $\mathrm{SO}_{2}$ and two $\mathrm{SO}_{4}$ measurements by dif- ferent institutional teams, if there are two measurements at any location along the flight paths, we used the average. If there was only one measurement, we used it directly. If there was no data, we treated it as missing value. We then calculated $\mathrm{SO}_{\mathrm{x}}=\mathrm{SO}_{2}+\mathrm{SO}_{4}$. For locations with no $\mathrm{SO}_{2}$ or $\mathrm{SO}_{4}$ data, we treated it as missing value. The vertical structures constructed by binning data every $500 \mathrm{~m}$ and averaging them, show that sulfurwas enhanced from the surface to $\sim 3-$ $4 \mathrm{~km}$. The observed average surface sulfur over this region was $\sim 1.8$ ppb below $500 \mathrm{~m}$. The predictions show the lowest sulfur (and the highest biases) in the $60 \mathrm{~km}$ base case. The $12 \mathrm{~km}$ base case also under-predicted total sulfur at all altitudes, but were improved over the $60 \mathrm{~km}$ base predictions.

Comparisons of observed and modeled $\mathrm{SO}_{2}$ and $\mathrm{SO}_{4}$ along all DC-8 flight paths over the three regions are shown as vertical profiles in Fig. $7 \mathrm{~g}$ and $\mathrm{h}$. The GIT $\mathrm{SO}_{2}$ is lower than the CIT $\mathrm{SO}_{2}$ below $1 \mathrm{~km}$ and higher at $\sim 1-3 \mathrm{~km}$. The two sets of measured $\mathrm{SO}_{4}$ follow the same trend below $\sim 1.5 \mathrm{~km}$, but CU Boulder $\mathrm{SO}_{4}$ is $\sim 10-20 \%$ lower than the $\mathrm{UNH} \mathrm{SO}$, and both teams observed $\mathrm{SO}_{4}$ aloft at $2-4 \mathrm{~km}$. The $60 \mathrm{~km}$ base case predicted the lowest $\mathrm{SO}_{2}$ and $\mathrm{SO}_{4}$. The $12 \mathrm{~km}$ base case $\mathrm{SO}_{2}$ generally followed the CIT $\mathrm{SO}_{2}$, but was biased low by $\sim 50 \%$ at the surface. The general vertical structure of $\mathrm{SO}_{4}$ was captured, but was more than $50 \%$ under-predicted at most altitudes.

The comparisons of observed and modeled $\mathrm{SO}_{2}$ and $\mathrm{SO}_{4}$ along all DC-8 flight paths (at all altitudes) are summarized in Table 3. The $\mathrm{R}$ values between modeled and observed $\mathrm{SO}_{\mathrm{x}}$, the Mean Biases (MB) as well as Root Mean Square Error (RMSE) of modeled $\mathrm{SO}_{2}$ and $\mathrm{SO}_{4}$ are listed. The higher correlations and lower errors are in bold. The $60 \mathrm{~km}$ base case predicted lower $\mathrm{SO}_{2}$ and $\mathrm{SO}_{4}$, and showed the weaker correlations with the observations. The $12 \mathrm{~km}$ base case improved the modeled $\mathrm{SO}_{2}$ and $\mathrm{SO}_{4}$ in magnitudes and correlations. As the partitioning between $\mathrm{SO}_{2}$ and $\mathrm{SO}_{4}$ is highly dependent on $\mathrm{OH}$ we also compared predicted $\mathrm{OH}$ and found that the $12 \mathrm{~km}$ base case had higher correlation than the $60 \mathrm{~km}$ case $(0.47$ compared to 0.41 , respectively).

In addition to the comparisons of modeled $\mathrm{SO}_{\mathrm{x}}$ along the DC-8 flight tracks, we also compare the predicted $\mathrm{SO}_{2}$ and $\mathrm{SO}_{4}$ with surfaces sites. Figure 8a shows the averaged 15:00-24:00 UTC (08:00-17:00 local time) $\mathrm{SO}_{2}$ at the six $\mathrm{SC}$ surface sites (locations shown in Fig. 1a). The $60 \mathrm{~km}$ base case under-predicted $\mathrm{SO}_{2}$ more than 10 times in general ( $60 \mathrm{~km}$ results were multiplied by 10 to be shown in figure). The $12 \mathrm{~km}$ base case under-predicts by a factor of two overall, but produce higher maximum, minimum (not shown) and mean $\mathrm{SO}_{2}$ values than $60 \mathrm{~km}$, and are closer to the observations.

Fine aerosol $\mathrm{SO}_{4}$ (diameter 0-2.5 $\mu \mathrm{m}$ ) mass was measured at multiple AQS (STN) ground sites over California on 20 and 23 June, and at IMPROVE sites on the same days. These sites represent the fine $\mathrm{SO}_{4}$ distributions over urban and rural areas, respectively. In addition, the total $\mathrm{SO}_{4}$ mass was measured and analyzed once a week at six California 

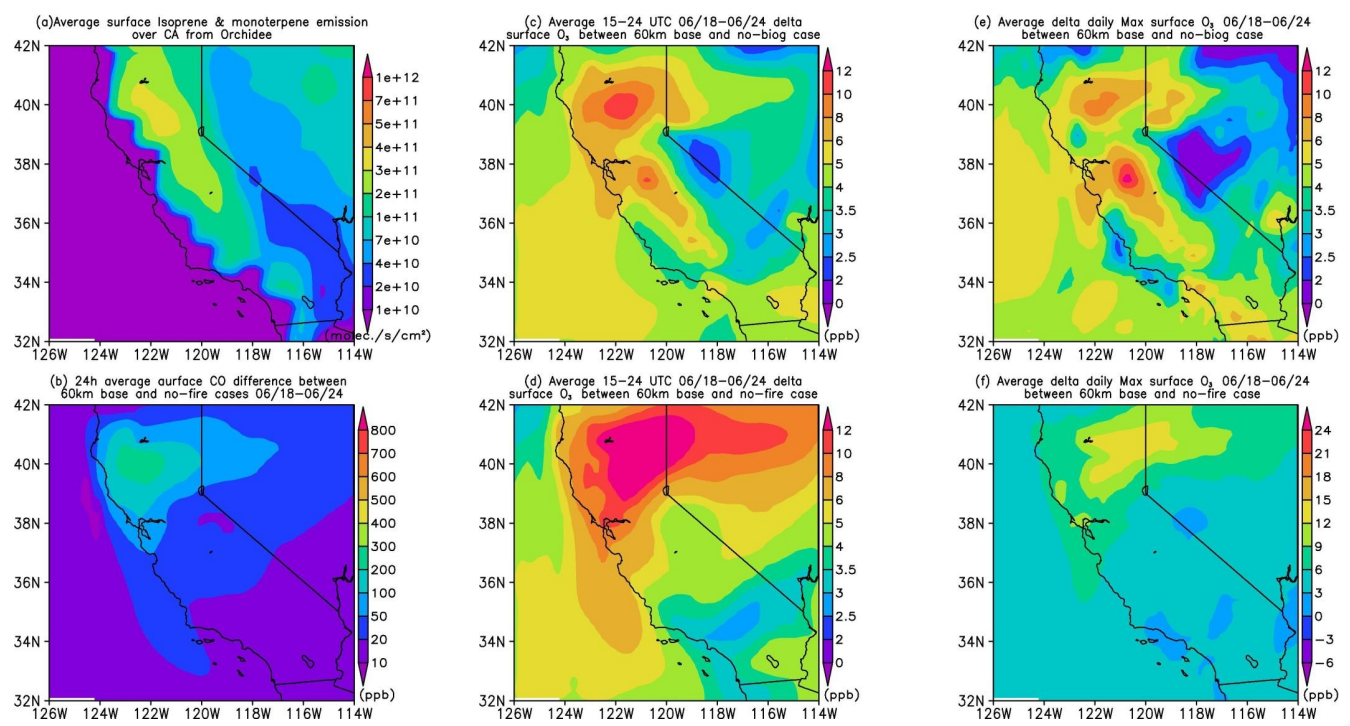

Fig. 6. (a) Average surface isoprene and monoterpene emissions from the Orchidee EI. (b) 24h-average differences of surface CO between base and no-fire cases in $60 \mathrm{~km}$ grids; Surface $\mathrm{O}_{3}$ differences between (c, e) base and no-biogenic cases and (d, f) base and no-fire cases of (c-d) averaged 15:00-24:00 UTC (08:00-17:00 UTC) and (e-f) average daily maximum $\mathrm{O}_{3}$ in $60 \mathrm{~km}$ grids.

Table 3. Correlation $(R)$, Mean Biases (MB), Root Mean Square Error (RMSE) between modeled and observed $\mathrm{SO}_{\mathrm{x}}$ along all $\mathrm{SC}$ flight tracks (all altitudes). Higher correlations, lower MB and RMSEs are in bold. Note that model comparisons refer to SC locations where measurements are available for individual teams, and the compared locations differ between teams.

\begin{tabular}{|c|c|c|c|c|c|c|c|}
\hline \multirow[t]{2}{*}{ Measurements } & \multicolumn{2}{|c|}{$R$ (observations vs. predictions) } & \multirow{2}{*}{$\begin{array}{l}\text { Observed } \\
\text { Mean } \\
(\mathrm{ppb})\end{array}$} & \multicolumn{2}{|c|}{ Mean Biases (ppb) } & \multicolumn{2}{|c|}{ RMSE (ppb) } \\
\hline & $12 \mathrm{~km}$ Base & $60 \mathrm{~km}$ Base & & $12 \mathrm{~km}$ Base & $60 \mathrm{~km}$ Base & $12 \mathrm{~km}$ Base & $60 \mathrm{~km}$ Base \\
\hline $\mathrm{CIT} \mathrm{SO}_{2}$ & 0.36 & 0.28 & 1.08 & 0.41 & 1.02 & 1.55 & 1.87 \\
\hline $\mathrm{GIT} \mathrm{SO}_{2}$ & 0.43 & 0.20 & 0.62 & 0.13 & 0.57 & 0.81 & 1.02 \\
\hline $\mathrm{UNH} \mathrm{SO}_{4}$ & 0.54 & 0.28 & 0.53 & 0.30 & 0.47 & 0.39 & 0.54 \\
\hline $\mathrm{CUB} \mathrm{SO}_{4}$ & 0.50 & 0.22 & 0.42 & 0.22 & 0.38 & 0.40 & 0.53 \\
\hline
\end{tabular}

CASTNET sites, which are located at remote areas. Some CASTNET and IMPROVE sites are co-located. There are several AQS(STN) and IMPROVE sites located in SC domain, as Fig. 8b shows. No CASTNET sites are located in the SC domain (Fig. 8c).

These $\mathrm{SO}_{4}$ observations are compared with results from both $12 \mathrm{~km}$ and $60 \mathrm{~km}$ simulations in Fig. $8 \mathrm{~b}$ and c. The predictions from both cases are biased low by about a factor of two to three. The $12 \mathrm{~km}$ case results are improved over the $60 \mathrm{~km}$ predictions by more than a factor of two at the CASTNET and IMPROVE sites statewide and within SC, and slightly improved at STN sites.

From both modeled and observed $\mathrm{SO}_{4}$ masses, it is found that during the flight week the surface values varied spatially according to: urban (AQS-STN) > rural and remote (IMPROVE CASTNET) areas, and both SC urban and rural areas had higher fine $\mathrm{SO}_{4}$ than the statewide average.
Table 4. Ratios of observed and the $12 \mathrm{~km}$ simulated $\mathrm{SO}_{\mathrm{x}}$.

\begin{tabular}{lcl}
\hline & $\begin{array}{l}\text { (flight time) all SC } \\
\text { flight observed/12 km predicted }\end{array}$ & $\begin{array}{l}(24 \mathrm{~h}) \text { surface observed/ } \\
12 \mathrm{~km} \text { predicted }\end{array}$ \\
\hline $\mathrm{SO}_{2}$ & 1.71 & 1.35 (SC CARB) 1.79 for \\
& & times 15:00-24:00 UTC \\
$\mathrm{SO}_{4}$ & 2.48 & 2.56 (Statewide CASTNET) \\
$\mathrm{Fine} \mathrm{SO}_{4}$ & 3.17 & 2.5 (SC STN+IMPROVE) \\
\hline
\end{tabular}

In general, the $12 \mathrm{~km}$ results provide closer results to both flight and surface observations during the simulation week. We calculated the ratios of averaged observations over $12 \mathrm{~km}$ results along the flight paths and at surface sites in SC (Table 4). In general, the $12 \mathrm{~km}$ simulations underestimated $\mathrm{SO}_{2}$ by up to $\sim 1.8$ times and $\mathrm{SO}_{4}$ by more than 2.5 times. During the flight periods, the ratios of the under-prediction along 

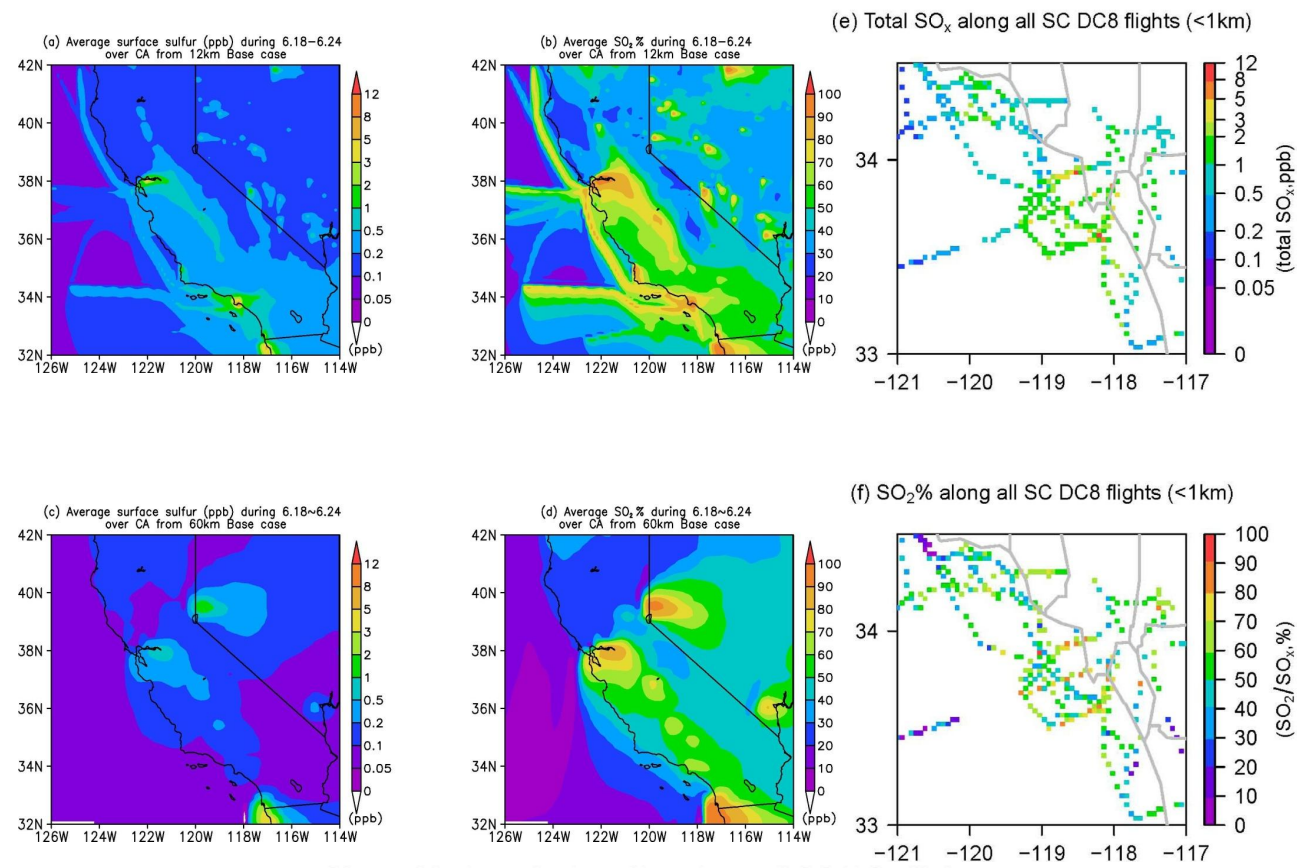

Obs. \& Mod. vertical profiles along all SC DC8 flights

(g) $\mathrm{SO}_{2}$

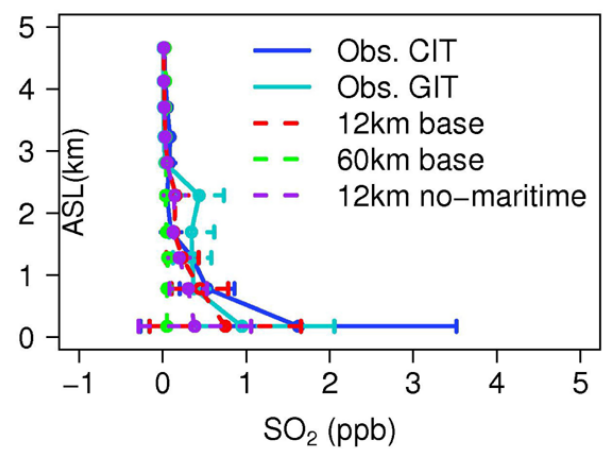

(i) $\mathrm{SO}_{\mathrm{x}}$

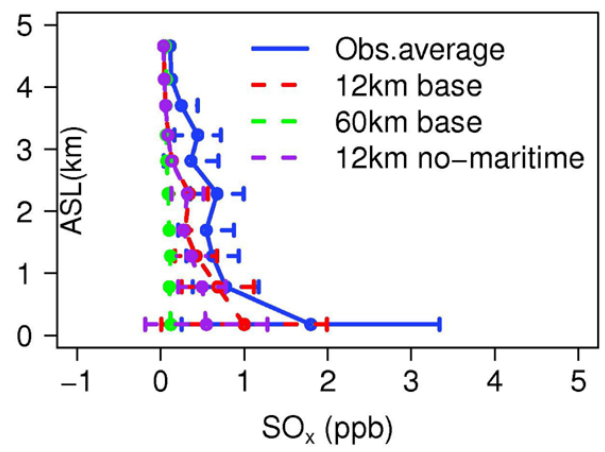

(h) $\mathrm{SO}_{4}$

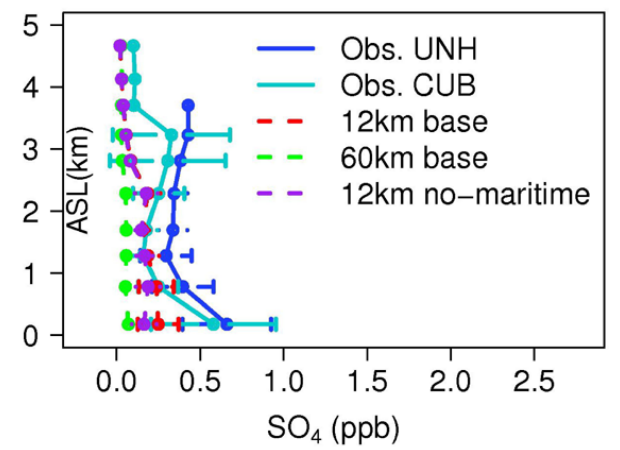

Fig. 7. The 24-h average surface (a, c) total $\mathrm{SO}_{\mathrm{x}}$ and (b, d) $\mathrm{SO}_{2} \%$ from $12 \mathrm{~km}(\mathbf{a}-\mathbf{b})$ and $60 \mathrm{~km}(\mathbf{c}-\mathbf{d})$ base simulations during the flight week; Observed (e) total $\mathrm{SO}_{\mathrm{x}}$ and (f) $\mathrm{SO}_{2} \%$ along all SC flights below $1 \mathrm{~km}$. Observed and modeled (g) $\mathrm{SO}_{2}$ (h) $\mathrm{SO}_{4}$ and (i) $\mathrm{SO}_{\mathrm{x}}$ vertical profiles along all SC flights (averaged every $500 \mathrm{~m}$ ). 
(a)

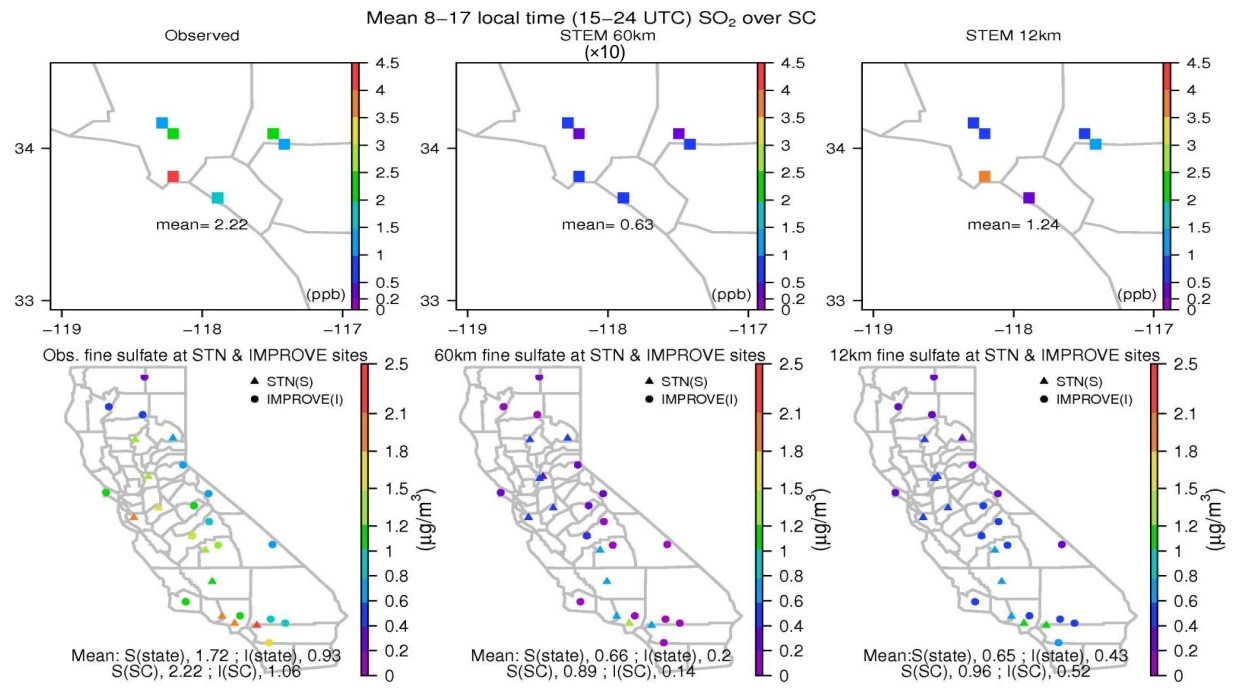

(c)
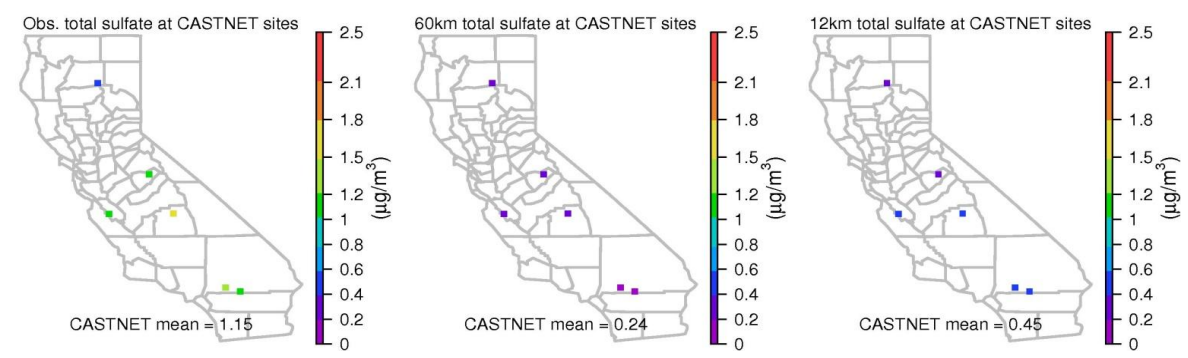

Fig. 8. (a) Observed and modeled average 15:00-24:00 UTC (08:00-17:00 local time) $\mathrm{SO}_{2}$ at six SC surface sites; (b) Observed and modeled average fine $\mathrm{SO}_{4}$ from STN and IMPROVE sites; (c) Observed and modeled average total $\mathrm{SO}_{4}$ from six CASTNET sites during the flight week.

flight paths and at six surface sites were similar (1.71 and 1.79 , respectively).

A similar analysis for $\mathrm{SO}_{\mathrm{x}}$ was done over the $\mathrm{SF}$ and $\mathrm{CV}$ regions (Fig. 1b) and we suggest further improvement on EIs over these regions as well. In general, by using the CARB $\mathrm{EI}$, the model underestimated $\mathrm{SO}_{\mathrm{x}}$ concentrations by a factor of up to 2 in the SF region and more than 10 times around Fresno, and using NEI produced higher negative discrepancies. A more quantitative analysis of model biases for these regions was limited by the fact that many fewer flight observations were made over these regions during the experiment. In order to improve EIs over these regions, further studies are needed.

\subsection{The identification of the contributors to the elevated $\mathrm{SO}_{\mathrm{x}}$ concentrations}

Figure $7 \mathrm{~g}-\mathrm{i}$ shows that $\mathrm{SO}_{\mathrm{x}}$ was elevated along the $\mathrm{SC}$ flight tracks near surface and between $2-4 \mathrm{~km}$. To better understand the possible source contributors to the elevated $\mathrm{SO}_{\mathrm{x}}$ levels near the surface, we summarize the VOC age and CO contributions in Table 5 for flight segments below $1 \mathrm{~km}$ us- ing the tracer calculations. VOC age was described in detail by Tang et al. (2004), which represents a combination of transport time, source intensities and diffusion, by using ethane as an indicator that is related to ethane emission and decay rate. During the experiment week, most of the flightsampled airmasses had anthropogenic China $\mathrm{CO} \%$ contributions less than $0.5 \%$ and North America CO $\%>99 \%$, except the airmasses on 24 June during 23:00-24:00 UTC (during flight) that had China CO $\%$ of $\sim 40 \%$. These airmasses are described in detail in Sect. 3.5.

In order to identify the airmass sources that caused the elevated sulfur aloft over SC between $2-4 \mathrm{~km}$ (Fig. $7 \mathrm{~g}-\mathrm{i}$ ), we analyzed back-trajectories originating along the three $\mathrm{SC}$ DC-8 flight paths at $2-4 \mathrm{~km}$ a.s.l. on individual flight days, based on the $12 \mathrm{~km}$ meteorological fields. During the flights on 18 and 24 June, the air was lifted and moved from the Central Valley. In contrast, during the other flight day, airmasses were from the southwest, and they descended from $>3500 \mathrm{~m}$ to SC (not shown in figures). 
Obs. \& Mod. along 06/22 DC8 flights (outbound)

(a) $\mathrm{SO}_{4}$ vertical profiles

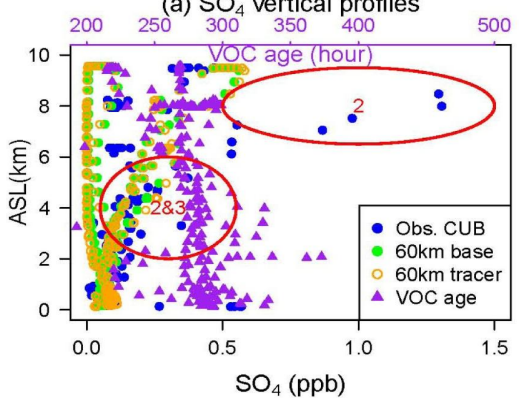

(b) $\mathrm{SO}_{2}$ vertical profiles

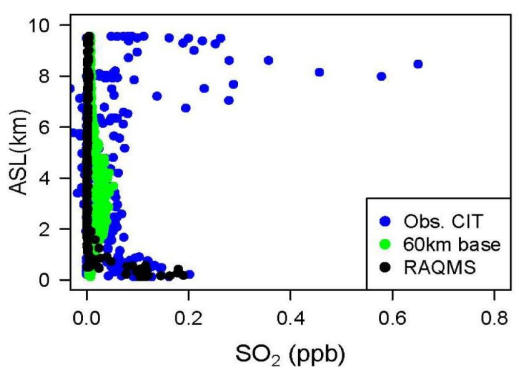

(c) $\mathrm{SO}_{4}$ \& flight altitude time series

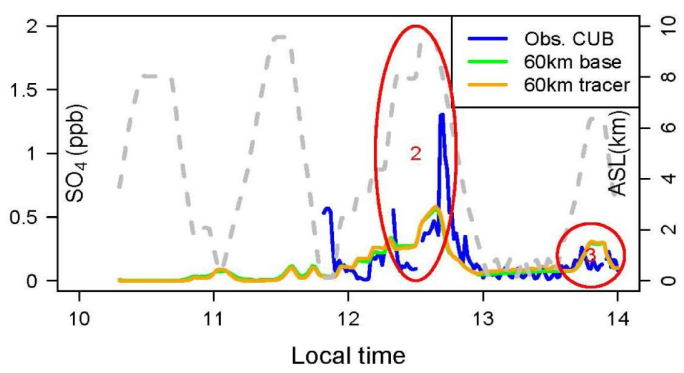

(d) $\mathrm{SO}_{2}$ \& flight altitude time series

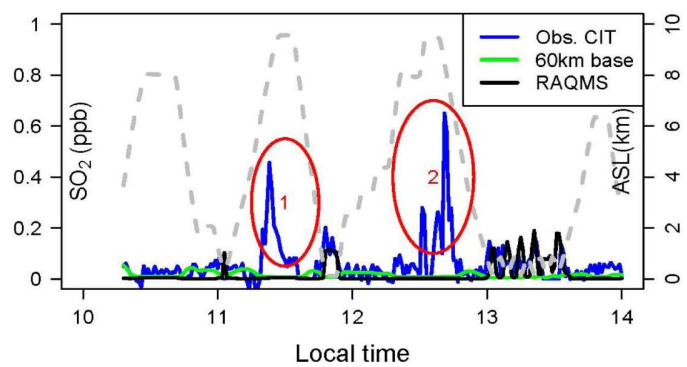

Five day back trajectories every 15 minutes along the

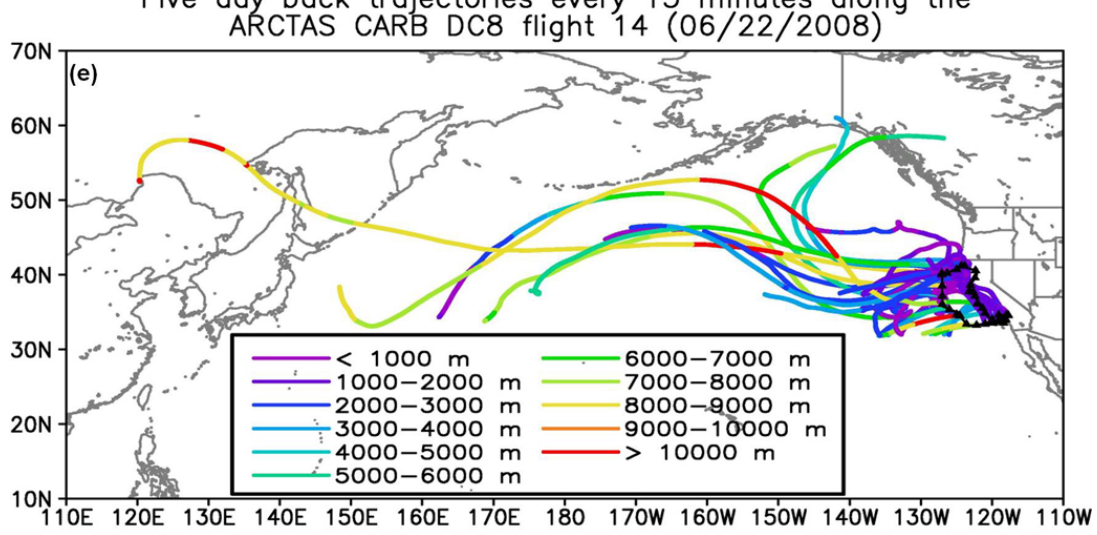

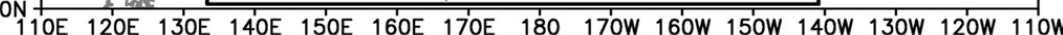
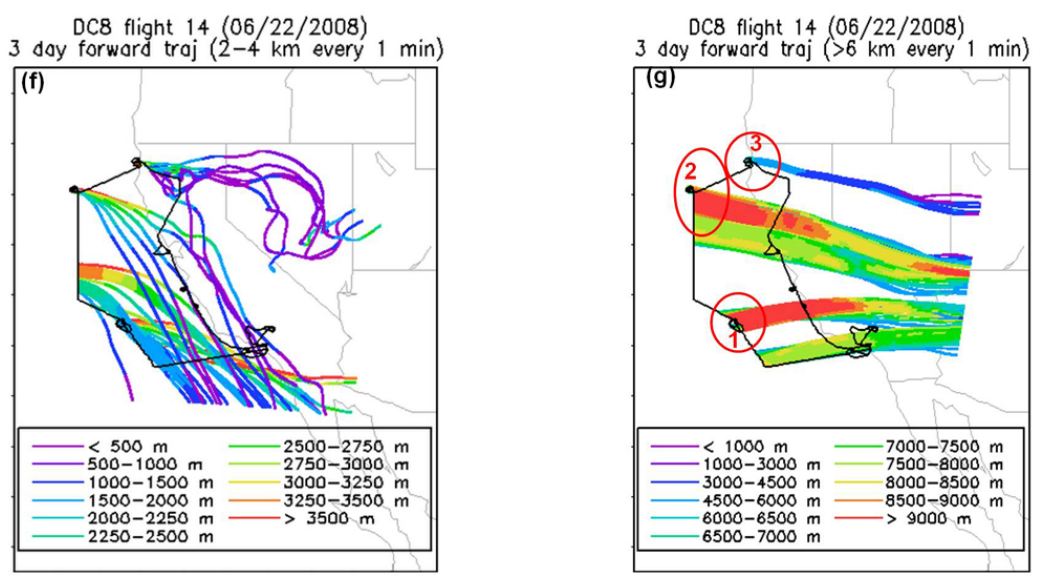

Fig. 9. Vertical profiles for (a) $\mathrm{SO}_{4}$ (with tracer-calculated VOC age) and (b) $\mathrm{SO}_{2}$ and time series (with flight altitudes) for (c) $\mathrm{SO}_{4}$ and (d) $\mathrm{SO}_{2}$ along outbound part of boundary layer flight on 22 June; (e) Back trajectories ending at the 22 June flight path (f) Three-day forward trajectories (a.s.l. 2-4 km) and (g) three-day forward trajectories (a.s.l. $>6 \mathrm{~km}$ ) starting from the outbound of the 22 June flight path. 
Table 5. Air-mass properties below $1 \mathrm{~km}$ a.s.l. along three SC flight paths from observations and tracer calculations.

\begin{tabular}{|c|c|c|c|c|c|c|c|c|c|}
\hline Flight day & $\begin{array}{l}\text { VOC age } \\
\text { (hour) }\end{array}$ & $\begin{array}{l}\text { China CO } \\
(\%)\end{array}$ & $\begin{array}{l}\text { North America CO } \\
(\%)\end{array}$ & $\begin{array}{l}\mathrm{SO}_{4}-\mathrm{UNH} \\
(\mathrm{ppb})\end{array}$ & $\begin{array}{l}\mathrm{SO}_{4} \text {-CUB } \\
(\mathrm{ppb})\end{array}$ & $\begin{array}{l}\mathrm{SO}_{2}-\mathrm{CIT} \\
(\mathrm{ppb})\end{array}$ & $\begin{array}{l}\mathrm{SO}_{2}-\mathrm{GIT} \\
(\mathrm{ppb})\end{array}$ & $\begin{array}{l}\mathrm{SO}_{4} \text { enhancements by } \\
\text { foreign sources }(\mathrm{ppb})\end{array}$ & $\begin{array}{l}\mathrm{SO}_{2} \text { enhancements by } \\
\text { foreign sources (ppb) }\end{array}$ \\
\hline 18 June SC & 11.26 & 0.01 & 99.94 & 0.6 & 0.44 & 1.31 & 0.87 & $3.1 \times 10^{-4}$ & $6.5 \times 10^{-4}$ \\
\hline 22 June SC & 10.73 & 0.2 & 99.74 & 0.55 & 0.56 & 1.37 & I & $1.4 \times 10^{-3}$ & $3.6 \times 10^{-3}$ \\
\hline 24 June SC & 15.78 & $\begin{array}{l}16.61,(\sim 40 \% \\
23: 00-24: 00 \text { UTC })\end{array}$ & $\begin{array}{l}78.42,(\sim 40 \% \\
23: 00-24: 00 \mathrm{UTC})\end{array}$ & 0.63 & 0.58 & 1 & 0.55 & 0.13 & 0.12 \\
\hline
\end{tabular}

\subsection{Long-range transport events}

Long-range transport of pollutants from Asia is typically assumed to be weaker and less frequent during summertime relative to springtime. During the ARCTAS-CARB experiment week, the 22 June flight aimed at characterizing the upwind boundary conditions necessary to model inland $\mathrm{O}_{3}$ and aerosols (Jacob et al., 2010). On this day, the DC-8 took off from Palmdale, CA, flew over the Pacific Ocean to Trinidad Head (a northern California site shown suitable for studying airmass entering the western US), and then circled back to Palmdale along the coast (Fig. 1b). At the outbound part of this flight (approximating 17:00-21:00 UTC), strong Asian inflows were encountered, as indicated from the VOC age (ranging from 200-400 h) shown in Fig. 9a, together with the back trajectories based on the $60 \mathrm{~km}$ WRF meteorology fields in Fig. 9e. Vertical profiles and time series of observed and modeled $\mathrm{SO}_{2}$ and $\mathrm{SO}_{4}$ are shown in Fig. 9a-d for this flight. Red circles in figures match elevated $\mathrm{SO}_{\mathrm{x}}$ concentrations in vertical profiles and time series plots to spatial locations shown in Fig. 9g. The $60 \mathrm{~km}$ tracer and $60 \mathrm{~km}$ full-chemistry simulated $\mathrm{SO}_{4}$ are compared with the observations in Fig. 9a-b. (The LBCs used in the $60 \mathrm{~km}$ full-chemistry simulations were taken from the $60 \mathrm{~km}$ tracer $\mathrm{SO}_{4}$ predictions and the $12 \mathrm{~km}$ full-chemistry simulations used LBCs from the $60 \mathrm{~km}$ full-chemistry results). Both the models captured the magnitudes of $\mathrm{SO}_{4}$ at $2-4 \mathrm{~km}$ fairly well. Elevated $\mathrm{SO}_{4}$ was also observed at $6-8 \mathrm{~km}$ a.s.l. (up to $\sim 1.3 \mathrm{ppb}$ ), mainly at location 2 and partially at location 3, by the CUB team. These airmasses were also high in China CO\% based on the tracer model calculations at $6-8 \mathrm{~km}$ (Fig. 9a). Three-day forward trajectories originating from $>6 \mathrm{~km}$ a.s.l. flight heights based on the $12 \mathrm{~km}$ WRF meteorology fields are shown in Fig. 9g, and the airmasses at these heights generally traveled above $3 \mathrm{~km}$ a.g.l. over California and thus did not impact the CA surface concentrations.

At flight location 3 (THD), the DC-8 also observed slightly enhanced $\mathrm{SO}_{4}$ at $1-4 \mathrm{~km}$ (Fig. 9a). In a previous study, we concluded that elevated $\mathrm{O}_{3}$ levels at $2-4 \mathrm{~km}$ on the same flight day in the eastern Pacific can be transported into the northern Central Valley, and contribute to the elevated surface $\mathrm{O}_{3}$ at inland locations. These airmasses containing elevated $\mathrm{SO}_{4}$ are also transported further into southern California (Fig. 9f). We estimate that these airmasses contributed $\sim 0.13$ ppb to near-surface $\mathrm{SO}_{4}$ levels over $\mathrm{SC}$ on 24 June, as summarized in Table 5. The upper limit enhancements of $\mathrm{SO}_{4}$ by foreign airmasses along the SC flight paths are calculated by Eq. (2)

Enhancements $=(1-$ North America $\mathrm{CO} \%) \times$ average $\mathrm{SO}_{\mathrm{x}}$ by two teams

$\mathrm{SO}_{2}$ peaks $(<0.7 \mathrm{ppb})$ were also observed by the CIT team at $6-8 \mathrm{~km}$ a.s.l. at flight locations 1 and 2 . These were the residuals in Asian plumes, as indicated by similar peaks for a number of observed species and the tracer calculations (not shown). The RAQMS and the $60 \mathrm{~km}$ base case results used as boundary conditions missed the $\mathrm{SO}_{2}$ peaks at both locations 1 and 2, but as discussed for $\mathrm{SO}_{4}$, these airmasses containing high $\mathrm{SO}_{2}$ did not affect California surface air quality. Around $0.1 \mathrm{ppb}$ of near-surface $\mathrm{SO}_{2}$ was attributed to foreign sources (Table 5), and the boundary conditions captured $\mathrm{SO}_{2}$ levels at $2-4 \mathrm{~km}$ very well (Fig. 9b).

\section{6 $\mathrm{SO}_{\mathrm{x}}$ local emissions - Emission Inventory comparisons}

As the local emissions mainly contributed to the elevated $\mathrm{SO}_{\mathrm{x}}$ concentrations near the surface during the experiment period, it is important to understand the contributions of the local sources. Therefore the emission inventory is one of the most important model inputs affecting the model-simulated near-surface $\mathrm{SO}_{\mathrm{x}}$ concentrations.

Figure 10 compares the 24-h average surface $\mathrm{SO}_{\mathrm{x}}$ emissions during 18-24 June from the CARB EI and NEI 2001 EI simulations (12 km and $60 \mathrm{~km}$ cases) over SC. Shipping emissions are included in the CARB EI,but are not in the NEI 2001, and the terrestrial $\mathrm{SO}_{2}$ emissions in NEI 2001 are generally much lower as shown in Fig. $10 \mathrm{a}$ and b. Figure 10c compares the time series of the average emission rates over the six SC surface sites from both EIs. The CARB EI peaks around noon time, while the NEI shows sharper later afternoon peaks (p.m. rush hours). The magnitudes in CARB emission rates are much higher than NEI, $\sim 12$ times for the $24 \mathrm{~h}$ averaged emission rates at the six sites $\left(6 \times 10^{10}\right.$ and $5 \times 10^{9}$ molecules $/ \mathrm{cm}^{2} / \mathrm{s}$, respectively).

Table 6 quantifies the mean and maximum surface $\mathrm{SO}_{\mathrm{x}}$ emission rates in $\mathrm{SC}$ and the entire state from both EIs. The statewide mean and maximum emission rates from NEI are higher than the CARB EI. However, in SC, the situation is opposite. The largest $\mathrm{SO}_{\mathrm{x}}$ emission sources in $\mathrm{SC}$ and California in NEI and CARB EI also differs. In the CARB EI, 
Table 6. Maximum and mean $\mathrm{SO}_{\mathrm{x}}$ emission rates over California and $\mathrm{SC}$ from both EIs and their top emissions sectors.

\begin{tabular}{llcll}
\hline & & Maximum $\left(\mathrm{kg} \mathrm{S} / \mathrm{km}^{2} /\right.$ day) & Mean $\left(\mathrm{kg} \mathrm{S} / \mathrm{km}^{2} /\right.$ day) & Top Emission Sector \\
\hline \multirow{2}{*}{ CARB } & Statewide & 55.11 & 0.09 & Ships and commercial boats, $52.1 \%$ \\
& SC & 55.11 & 0.81 (regional total: 48.5 ton/day) & Ships and commercial boats, $44.6 \%$ \\
\multirow{2}{*}{ NEI } & Statewide & 173.14 & 0.13 & Fossil fuel combustion, $51.3 \%$ \\
& SC & 0.70 & 0.05 (regional total:4.91 ton/day) & Non-road equipment, $40.4 \%$ \\
\hline
\end{tabular}

- The sector emissions ranks in CARB and NEI documentations are for summertime South Coast Basin and yearly Los Angeles County, respectively, not the same as our SC domain, In their SC domain, CARB documented 2005 and 2010 summer $\mathrm{SO}_{\mathrm{x}}$ emissions are 51.46 ton/day and 38.83 ton/day, respectively.

- Data sources: http://www.epa.gov/air/emissions/so2.htm, http://www.arb.ca.gov/app/emsinv/t25cat/cat_top25.php.
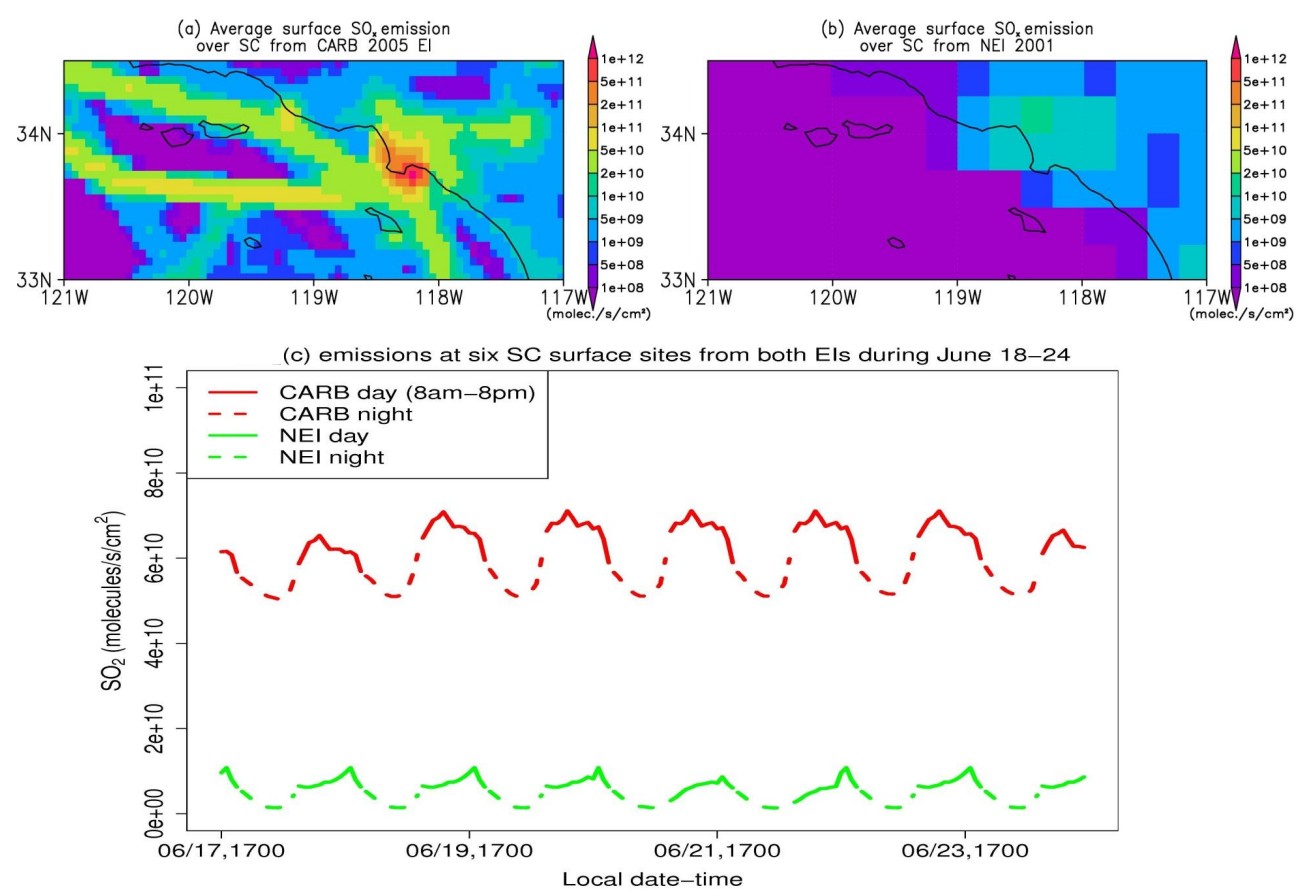

Fig. 10. The average surface $\mathrm{SO}_{\mathrm{x}}\left(\mathrm{SO}_{2}+\right.$ Primary $\left.\mathrm{SO}_{4}\right)$ during $18-24$ June over SC from (a) CARB EI and (b) $\mathrm{NEI} 2001$; (c) $\mathrm{SO}$ x surface emissions from both EIs during 18-24 June over SC, solid and dash lines represent day (08:00-20:00 local time) and night time, respectively.

the shipping emissions account for $52.1 \%$ and $44.6 \%$ of summertime $\mathrm{SO}_{\mathrm{x}}$ emissions for $\mathrm{SC}$ and the entire state, while in NEI, fossil fuel combustion and non-road equipment rank as the top emission sources in LA county and California, respectively. The regional total emissions from CARB EI (48.5 ton S/day) is $\sim 10$ times of that documented by NEI (4.91 ton S/day).

\subsection{Effects of maritime emissions on coastal SC air quality}

As analyzed in Sect. 3.6, shipping emissions over the SC (and other California coastal areas) account for more than $40-50 \%$ of total summertime $\mathrm{SO}_{\mathrm{x}}$ emissions. Therefore, the $\mathrm{SO}_{\mathrm{x}}$ levels at $\mathrm{SC}$ are impacted by both terrestrial (highway, port heavy transportations, industry) and maritime emissions (mainly shipping). As for the important $\mathrm{O}_{3}$ precursors, the maritime emissions account for $\sim 19 \%$ and $14.5 \%$ of the total $\mathrm{NO}_{\mathrm{x}}$ emissions in $\mathrm{SC}$ and the state, while VOC emissions from ships are negligible.

In order to better understand the model $\mathrm{SO}_{2}$ sensitivity with respect to $\mathrm{SO}_{2}$ at receptor sites (the six $\mathrm{SC}$ surface sites shown in Fig. 1a), adjoint sensitivity simulations are conducted. Specifically we perturbed $\mathrm{SO}_{2}$ concentrations at 00:00 UTC of each day during the flight weekand in the four surrounding model grids of all receptor sites. The influence function $\lambda\left[\mathrm{SO}_{2}\right]$ represents $\mathrm{SO}_{2}$ sensitivity at earlier times in various locations in response to the perturbations in $\mathrm{SO}_{2}$ at the receptors. The sensitivity runs for each day lasted for one day.

Figure 11a shows the weekly-averaged surface $\lambda\left[\mathrm{SO}_{2}\right]$ during the time periods (15:00-24:00 UTC), and Fig. 11c depicts the weekly-averaged $\lambda\left[\mathrm{SO}_{2}\right]$ vertical structures averaged over maritime and terrestrial grid cells during these 

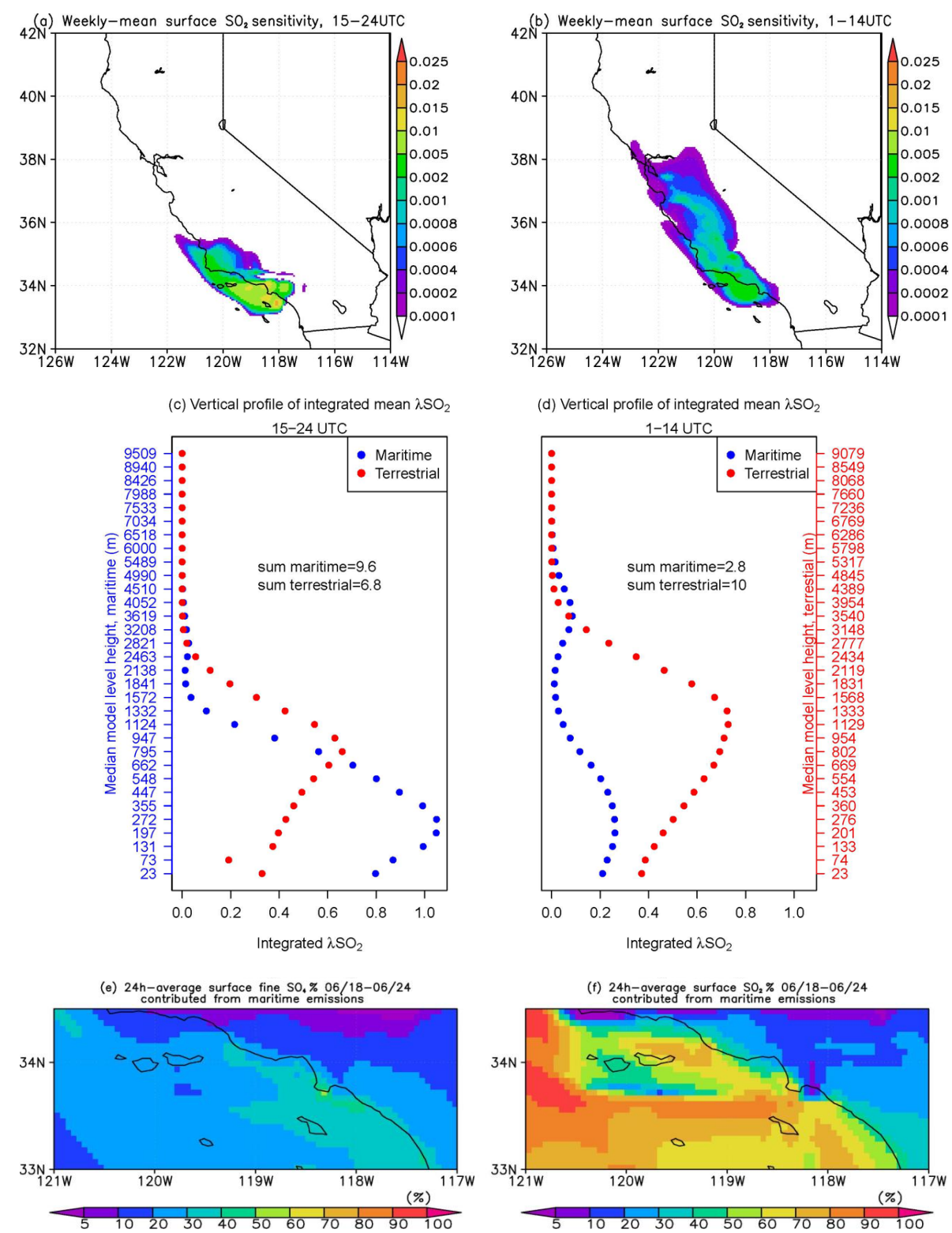

Fig. 11. Weekly mean surface $\mathrm{SO}_{2}$ sensitivity for (a) 15:00-24:00 UTC (b) 01:00-14:00 UTC; Vertical profile of integrated mean $\mathrm{SO}_{2}$ sensitivityfor (c) 15:00-24:00 UTC (d) 01:00-14:00 UTC; The 24-h averaged surface (e) $\mathrm{SO}_{4} \%$ and (f) $\mathrm{SO}_{2} \%$ contributed from maritime emissions over SC, calculated in $12 \mathrm{~km}$ grids.

times. $\mathrm{SO}_{2}$ at the $\mathrm{CARB}$ monitoring site receptors is more sensitive to the maritime $\mathrm{SO}_{2}$ levels than the terrestrial levels, especially over the surrounding areas of the ports and along the major shipping tracks, which reflect the impacts of the on-shore daytime transport associated with the sea breeze circulations during these periods. The vertical structures of $\lambda\left[\mathrm{SO}_{2}\right]$ reflect the modeled boundary layer structures over the land and ocean. The model level heights vary with location (for example, over the terrestrial regions, model level 10 ranges $730-860 \mathrm{~m}$ a.g.l. and over the oceanmodel level 5 is generally $<300 \mathrm{~m})$. Therefore, the integrated $\lambda\left[\mathrm{SO}_{2}\right]$ at each level are shown against the median model level height over the maritime and terrestrial regions.

Similarly, Fig. 11b shows the weekly-averaged surface $\lambda$ $\left[\mathrm{SO}_{2}\right]$ during the rest of the times (at night and early morning, 01:00-14:00 UTC, 18:00-07:00 LT), after the peak in daytime boundary layer height. Figure $11 \mathrm{~d}$ depicts the weeklyaveraged maritime and terrestrial $\lambda\left[\mathrm{SO}_{2}\right]$ vertical structures for these times. At these times, $\mathrm{SO}_{2}$ levels at the six $\mathrm{SC}$ sites are more sensitive to the terrestrial $\mathrm{SO}_{2}$ levels than the maritime levels, and the sensitivities are generally lower than during the daytime (15:00-24:00 UTC times), with smaller 

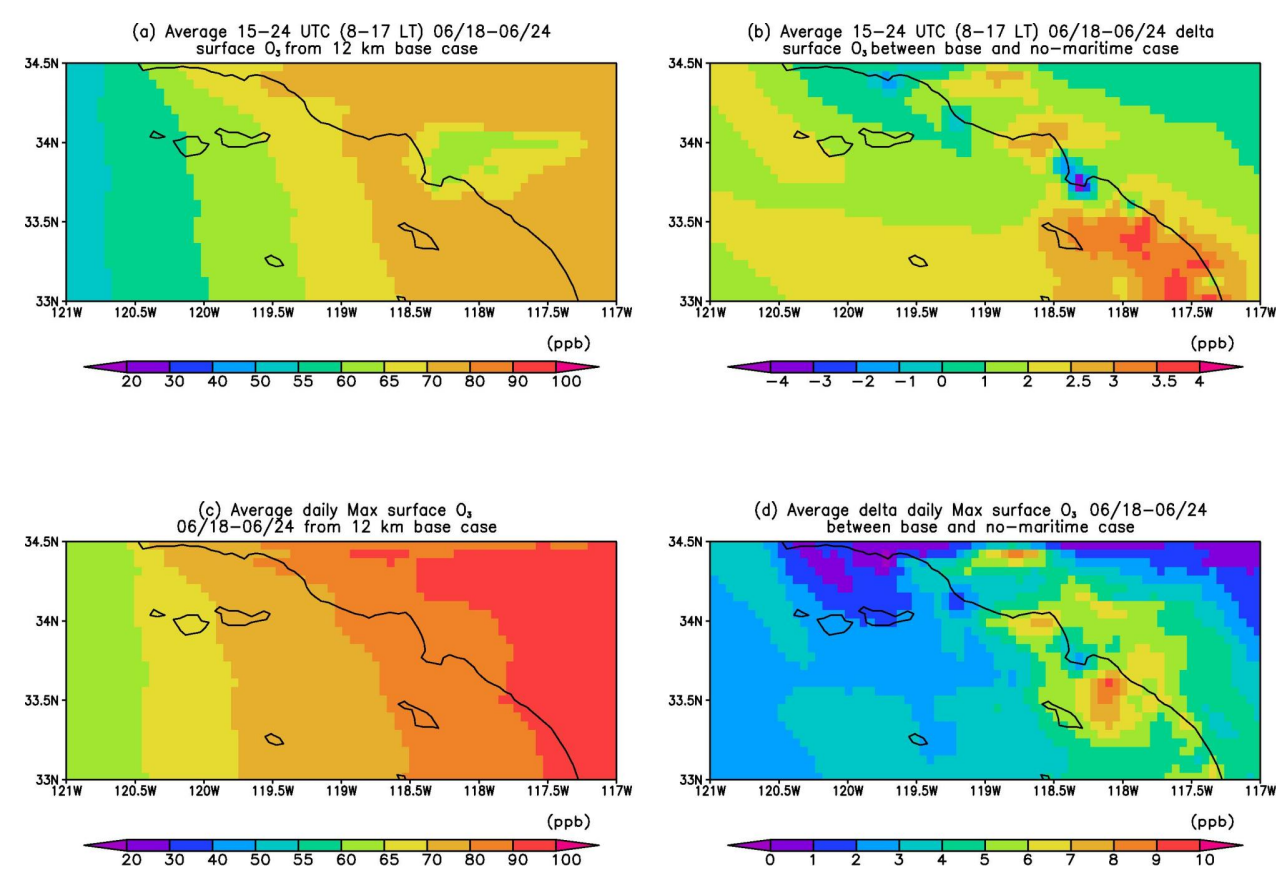

Fig. 12. (a) Averaged 15:00-24:00 UTC (08:00-17:00 local time) surface $\mathrm{O}_{3}$ from $12 \mathrm{~km}$ base case; (b) Averaged 15:00-24:00 UTC (08:0017:00 local time) surface $\mathrm{O}_{3}$ differences between $12 \mathrm{~km}$ base and no-maritime emission cases; (c) Average daily maximum surface $\mathrm{O}_{3}$ from $12 \mathrm{~km}$ base case; (d) Average daily maximum surface $\mathrm{O}_{3}$ differences between $12 \mathrm{~km}$ base and no-maritime emission cases during the flight week.

gradients. The sensitivity regions are shown to extend to the San Francisco Bay area, indicating the effects of regional transport. The vertical structures of $\lambda\left[\mathrm{SO}_{2}\right]$ reflect the transport of $\mathrm{SO}_{2}$ over the ocean during these times, which include the near-surface transport $(<300 \mathrm{~m})$, and transport at higher altitudes $(\sim 3.5 \mathrm{~km})$, the local contribution over the SC region, and the transport through terrestrial regions along the north and central coast areas. The maximum $\lambda\left[\mathrm{SO}_{2}\right]$ is found at altitudes $<\sim 1.5 \mathrm{~km}$ a.g.l. over land during these times.

To further understand the contributions from terrestrial and maritime emissions to sulfur and $\mathrm{O}_{3}$ concentrations over SC, we conducted an additional model simulation in the $12 \mathrm{~km}$ domain with only the terrestrial emissions from the CARB EI for all chemical species. The differences between the base case and the terrestrial-emission-only case provide an estimate of the contribution from maritime emissions.

Figure $11 \mathrm{e}$ and $\mathrm{f}$ illustrates the $24 \mathrm{~h}$-average contributions of maritime emissions on surface $\mathrm{SO}_{\mathrm{x}}$ concentrations during 15:00-24:00 UTC through the flight week. $\mathrm{SO}_{2}$ levels are directly affected by both terrestrial and maritime emissions as shown. The maritime emissions cause high $\mathrm{SO}_{2}$ levels over the ocean and on shore (where $\mathrm{SO}_{2}>60-70 \%$ of the total sulfur), with contributions to total $\mathrm{SO}_{2}$ levels ranging from $10-70 \%$. For $\mathrm{SO}_{4}$, the spatial distribution is highly influenced by reaction rates and the wind fields. SC is heavily under the impact of northwest winds during the daytime in this period. Consequently, the maritime emissions generally contributed $20-60 \%$ of fine $\mathrm{SO}_{4}$ along the coastaland inland areas, with the regions of influence extending as far as San Diego and the California - Mexico border area.

Figure $7 \mathrm{~g}-\mathrm{i}$ shows the change of the vertical distributions of $\mathrm{SO}_{\mathrm{x}}$ in response to cutting off maritime emissions along all SC DC-8 flight paths. During the flight periods, both $\mathrm{SO}_{2}$ and $\mathrm{SO}_{4}$ were reduced in the vertical up to $\sim 1500 \mathrm{~m}$. The maximum reduction of $\mathrm{SO}_{\mathrm{x}}$ (by $\sim 50 \%$ ) is shown at the lowest $500 \mathrm{~m}$. The differences in simulated $\mathrm{SO}_{2}$ in the $12 \mathrm{~km}$ base and terrestrial emission cases are $\sim 0.3-0.5 \mathrm{ppb}$ for each day during the week at the six surface sites (not shown).

The effects of maritime emissions on surface $\mathrm{O}_{3}$ levels are shown in Fig. 12. The average $\mathrm{O}_{3}$ changes during 15:0024:00 UTC for the flight week are below $\sim 4 \mathrm{ppb}$, and over the port areas (such as north Long Beach, the flight time average $\mathrm{O}_{3}$ increases by $3-4 \mathrm{ppb}$ after cutting off the maritime emissions. The averaged daily maximum $\mathrm{O}_{3}$ decrease by $3-$ $10 \mathrm{ppb}$ in the domain, and the decreases around north Long Beach are lower ( $\sim 3-4 \mathrm{ppb})$. Figure $3 \mathrm{f}$ shows the time series of $\mathrm{O}_{3}$ at the six SC surface sites from the no-maritime emission case, together with observations and $12 \mathrm{~km}$ and $60 \mathrm{~km}$ base $\mathrm{O}_{3}$ values. The differences in simulated $\mathrm{O}_{3}$ in the $12 \mathrm{~km}$ base and terrestrial emission cases are below $5 \mathrm{ppb}$, and the maximum changes occurred at afternoon peak time on 18 June.

To better understand the reduction of $\mathrm{SC}_{3}$ caused by maritime emissions, the changes of two $\mathrm{O}_{3}$ production indicator species $\left(\mathrm{NO}_{\mathrm{y}}\right.$ and $\left.\mathrm{O}_{3} / \mathrm{NO}_{\mathrm{y}}\right)$ are analyzed in Fig. 13. We first evaluate the model-predicted $\mathrm{NO}_{\mathrm{y}}$ concentrations 

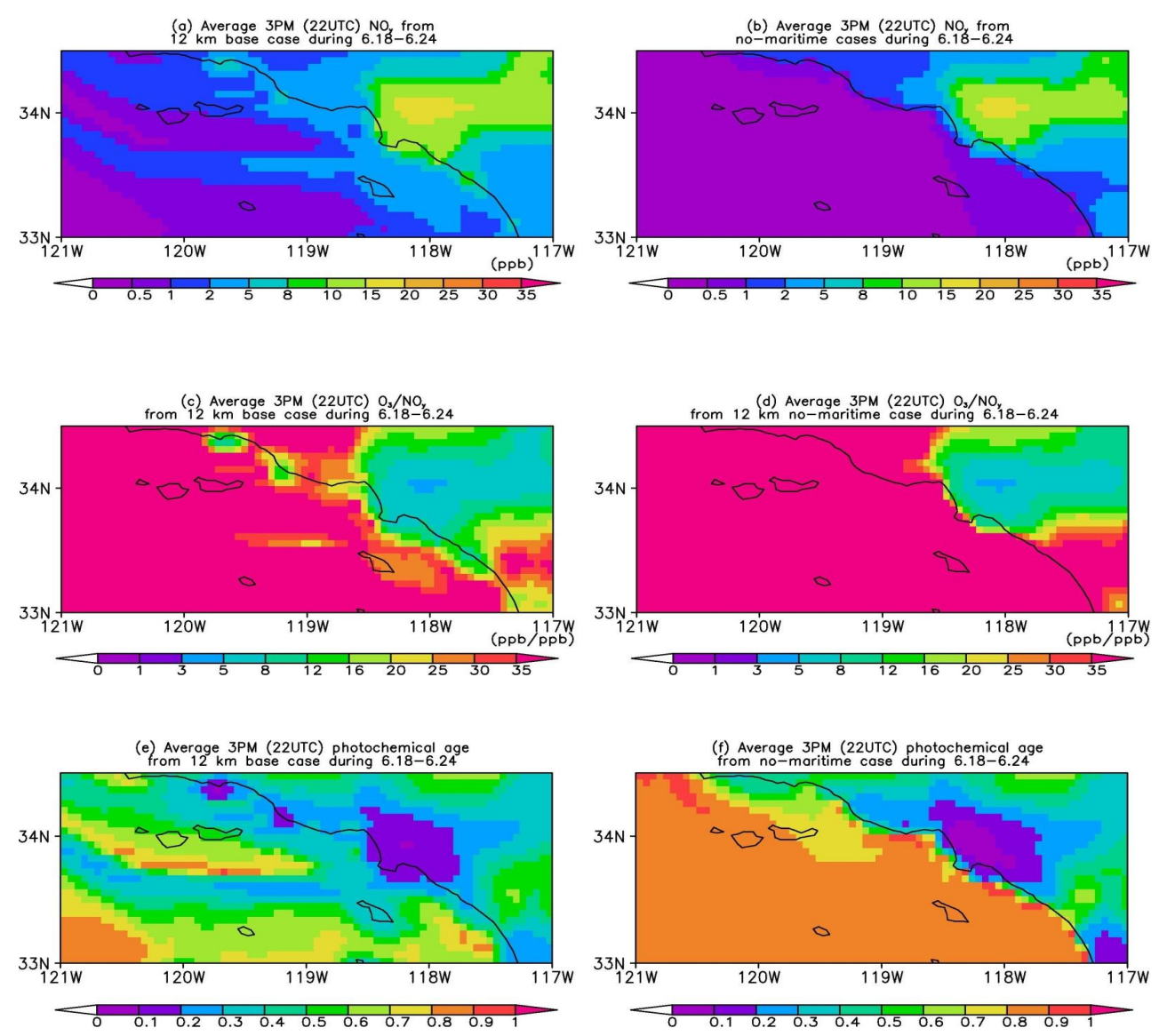

Fig. 13. (a) Average 22:00 UTC (15:00 local time) surface $\mathrm{NO}_{\mathrm{y}}$ from (a) $12 \mathrm{~km}$ base case and (b) $12 \mathrm{~km}$ no-maritime case; (c) Average 22:00 UTC (15:00 local time) surface $\mathrm{O}_{3} / \mathrm{NO}_{\mathrm{y}}$ from $12 \mathrm{~km}$ base case and (d) $12 \mathrm{~km}$ no-maritime case; (e) Average 22:00 UTC (15:00 local time) surface photochemical age $\left(\mathrm{NO}_{\mathrm{z}} / \mathrm{NO}_{\mathrm{y}}\right)$ from $12 \mathrm{~km}$ base case and (f) $12 \mathrm{~km}$ no-maritime case.

and $\mathrm{O}_{3} / \mathrm{NO}_{\mathrm{y}}$ ratios along all DC8 flights. Overall the model captured the main features of the spatial distributions for both of them, and the correlations of model predicted $\mathrm{NO}_{\mathrm{y}}$ and $\mathrm{O}_{3} / \mathrm{NO}_{\mathrm{y}}(<0.5 \mathrm{~km})$ were $R=0.53$ and 0.71 , respectively. The detailed validations of modeled $\mathrm{O}_{3} / \mathrm{NO}_{\mathrm{y}}$ and $\mathrm{NO}_{\mathrm{y}}$ with flight observations are described in Huang et al. (2011).

Averaged $\mathrm{NO}_{\mathrm{y}}$ and $\mathrm{O}_{3} / \mathrm{NO}_{\mathrm{y}}$ ratios at 15:00 (22:00 UTC) (the time of peak $\mathrm{O}_{3}$ and PBL height) during the flight week are shown for the base and no-maritime emission cases. When afternoon $\mathrm{NO}_{\mathrm{y}}<10-25 \mathrm{ppb}$, or/and $\mathrm{O}_{3} / \mathrm{NO}_{\mathrm{y}}>5-10$, the area belongs to the $\mathrm{NO}_{\mathrm{x}}$-limited $\mathrm{O}_{3}$ production regime (Milford et al., 1994; Sillman et al., 1995; Jacob et al., 1995). Based on these criteria, the SC urban area in the $12 \mathrm{~km}$ base case is estimated to be VOC limited. The removal of maritime emissions leads to flight time average $\mathrm{NO}_{\mathrm{y}}$ decreases of up to $>10 \mathrm{ppb}$, over the North Long Beach area, and the $\mathrm{O}_{3} / \mathrm{NO}_{\mathrm{y}}$ ratio rises up to 20 overthe regions south of Long Beach. This indicates that by cutting off the maritime emissions, some coastal areas can change from VOC-limited to $\mathrm{NO}_{\mathrm{x}}$-limited, or more $\mathrm{NO}_{\mathrm{x}}$-limited.
Photochemical age (PA) indicators such as $\mathrm{NO}_{\mathrm{z}} / \mathrm{NO}_{\mathrm{y}}$ help us to evaluate the airmass smog potential. When PA is more than $0.6-0.7$, smog potential is exhausted. Figure $13 \mathrm{e}$ and $\mathrm{f}$ show averaged at 15:00 (22:00 UTC) during the flight week for base and no-maritime emission cases. In both cases, PA are young $(<0.6)$ over terrestrial areas, while the base case shows younger PA along shipping tracks $(0.2-0.5)$, in contrast to PA in the no-maritime emission case $(>0.8)$. Removing maritime emissions leads to old PA over most on-shore areas but slightly younger PA over SC urban areas.

\section{Conclusions}

The chronic high surface $\mathrm{O}_{3}$ concentrations, as well as the increasing $\mathrm{SO}_{\mathrm{x}}$ ambient concentrations over California's south coast (SC) and other regions, are affected by both long-range transport and local emissions, as shown in previous (Huang et al., 2010) and this study. Asian inflows were shown to be important around 22 June, during which period the $\mathrm{O}_{3}$ concentrations in long-range transported air were $60-80 \mathrm{ppb}$. The transported air at $\sim 2-4 \mathrm{~km}$ contained $\sim 0.1-0.3 \mathrm{ppb}$ of 
$\mathrm{SO}_{4}$ (Fig. 9a) in average. Those airmasses descended to the surface and influenced surface concentrations. The contribution from long-range transport occurred first over northern California and then over SC through in-state transport on $\sim 24$ June, when up to $\sim 0.25 \mathrm{ppb}$ of surface $\mathrm{SO}_{\mathrm{x}}$ in $\mathrm{SC}$ was attributed to foreign sources (Table 5, upper-limit). During this period $\mathrm{SO}_{4}$ and $\mathrm{SO}_{2}$ in these long-range transported airmasses were also enhanced at altitudes above $6 \mathrm{~km}$, but were transported at inland at high altitudes and did not influence CA surface air quality.

The influence of local emissions from both natural and anthropogenic sources on air quality was evaluated. We conducted sensitivity simulations by turning off biogenic and fire emissions in both $12 \mathrm{~km}$ and $60 \mathrm{~km}$ model resolutions and compared the modeled $\mathrm{O}_{3}$ in base vs. sensitivity cases. We found that both biomass burning and biogenic emissions contribute to regional background $\mathrm{O}_{3}$ over $\mathrm{SC}$ up to $4 \mathrm{ppb}$, with larger contributions in other regions of CA (such as in the Central Valley, up to 10-12 and 12-15 ppb from biogenic and fire emissions, respectively). Uncertainties in these estimates due to model resolutions, emissions inventories and other factors are on the order of 3-4 ppb over SC.

The high concentrations of SC surface $\mathrm{SO}_{\mathrm{x}}$ during the flight week were mostly contributed by local emissions. We compared two anthropogenic $\mathrm{SO}_{\mathrm{x}}$ EIs applied in $60 \mathrm{~km}$ and $12 \mathrm{~km}$ simulations and evaluated the model performance. The EIs vary temporally and spatially, but the NEI 2001 lacks the shipping emissions, and has lower emissions overall. The resulting predicted $\mathrm{SO}_{\mathrm{x}}$ concentrations are shown to be significantly underestimated. The CARB 2005 EI improved the magnitudes of emission rates and produced results closer to observations. However, the overall $\mathrm{SO}_{\mathrm{x}}$ emissions over the $\mathrm{SC}$ are found to be underestimated, and estimate that the CARB emissions are low by about factor of two.

Adjoint sensitivity analysis indicated that during the flight week, $\mathrm{SO}_{2}$ levels at 00:00 UTC at six SC surface sites were influenced by previous day maritime emissions over the ocean, the terrestrial emissions over nearbyurban areas, and by transported $\mathrm{SO}_{2}$ from the north, through both terrestrial and maritime areas.

We analyzed the effects of maritime emissions on air quality over SC by conducting a sensitivity simulation without maritime emissions using the CARB EI. The maritime emissions contributed $10-70 \%$ of $\mathrm{SO}_{2}$ concentrationsover onshore and terrestrial areas, showing apparent negative gradients from the coastal to inland regions. Approximately 20$60 \%$ of fine $\mathrm{SO}_{4}$ over the terrestrial regionsare attributed to the maritime emissions, and the impacts are extended to San Diego areas. The maritime emissions significantly increased the $\mathrm{NO}_{\mathrm{y}}$ distributions on shore, especially around the port area of North Long Beach. The $\mathrm{O}_{3}$ production in downwind areas can be shifted from VOC-limited to $\mathrm{NO}_{\mathrm{x}}$-limited after cutting off maritime emissions. Photochemical ages are also modified over on-shore areas as well as urban regions.
These results suggest that further improvements in $\mathrm{SO}_{\mathrm{x}}$ emission inventories for the studied region as well as its upwind regions (north and central coastal areas) are needed. Optimal methods (such as data assimilation) can provide complete emission scaling factor matrix and reduce the mismatches between observations and model simulations. These methods would benefit from high resolution continuous nearsurface measurements over both terrestrial and maritime areas. The impacts of one long-range transport event were analyzed during this one-week study period. Future studies over a longer period of time are needed to determine the frequency and variations in intensity of long range transport events and to identify the impacted regions during summertime. In addition, studies on reducing the uncertainties in estimated contributions from various emission sectors are also needed, which will support the future pollution control policies and regulations.

\section{Supplement related to this article is available online at: http://www.atmos-chem-phys.net/11/3173/2011/ acp-11-3173-2011-supplement.pdf.}

Acknowledgements. We would like to thank the ARCTAS science team and two anonymous reviewers. We thank Tianfeng Chai (NOAA/OAR/ARL) for helping with the STEM adjoint model. This work was supported by a NASA award (NNX08AH56G). Jose L. Jimenez and Michael J. Cubisonwere supported by NASA NNX08AD39G. The authors would also like to acknowledge NOAA, the US EPA and CARB for support of the ground measurements. The views, opinions, and findings contained in this report are those of the author(s) and should not be construed as an official NOAA or US Government position, policy, or decision.

Edited by: P. Monks

\section{References}

BST Associates: Trade impacts studyPrepared for Port of Los Angeles, Port of Long Beach and Almeda Corridor Transportation Authority. http://www.portoflosangeles.org/DOC/REPORT ACTA_Trade_Impact_Study.pdf, 2007.

Bytnerowicz, A., Cayan, D., Riggan, P., Schilling, S., Dawson, P., Tyree, M., Wolden, L., Tissell, R., and Preisler, H.: Analysis of the effects of combustion emissions and Santa Ana winds onambient ozone during the October 2007 southern California wildfires, Atmos. Environ., 44, 678-687, 2010.

Carmichael, G. R., Sandu, A., Chai, T., Daescu, D. N., Constantinescu, E. M., and Tang, Y.; Predicting air quality: Improvements through advanced methods to integrate modelsand measurements, J. Comp. Phys., 227, 3540-3571, doi:10.1016/j.jcp.2007.02.024, 2008.

Carter, W. P. L.: Implementation of the SAPRC-99 chemicalmechanism into the models-3 framework. Report to theUnited States Environmental Protection Agency, http://www.engr.ucr. edu/ carter/pubs/s99mod3.pdf, 2000. 
Chai, T., Carmichael, G. R., Tang, Y., Sandu, A., Heckel, A., Richter, A., and Burrows, J. P.: Regional $\mathrm{NO}_{2}$ emission inversion through four-dimensional variational approach using SCIAMACHY tropospheric column observations, Atmos. Environ., 43(32), 5046-5055, 2009

Chen, X. Ren, J. Mao, Z. Chen, W. H. Brune, B. Lefer, B. Rappenglück, J. Flynn, J. Olson and J. Crawford, A comparison of chemical mechanisms based on TRAMP-2006 field data, Atmos. Environ., 44, 4116-4125, 2010.

Corbett, J. J. and Fischbeck, P. S.: Emissions from ships, Science, 278, 823-824, 1997.

Cox, P., Delao, A., Komorniczak, A., and Weller, R.: The California almanac of emissions and air quality 2009 edition, http://www. arb.ca.gov/aqd/almanac/almanac09/almanac2009all.pdf, 2009.

Crounse, J. D., DeCarlo, P. F., Blake, D. R., Emmons, L. K., Campos, T. L., Apel, E. C., Clarke, A. D., Weinheimer, A. J., McCabe, D. C., Yokelson, R. J., Jimenez, J. L., and Wennberg, P. O.: Biomass burning and urban air pollution over the CentralMexican Plateau, Atmos. Chem. Phys., 9, 4929-4944, doi:10.5194/acp-9-4929-2009, 2009.

Davies, D. K., Ilavajhala, S., Wong, M. M., and Justice, C. O.: Fire Information for Resource Management System: Archiving and Distributing MODIS Active Fire Data. IEEE T. Geosci. Remote Sens., 47(1), 72-79, 2009.

Dunlea, E. J., DeCarlo, P. F., Aiken, A. C., Kimmel, J. R., Peltier, R. E., Weber, R. J., Tomlinson, J., Collins, D. R., Shinozuka, Y., McNaughton, C. S., Howell, S. G., Clarke, A. D., Emmons, L. K., Apel, E. C., Pfister, G. G., van Donkelaar, A., Martin, R. V., Millet, D. B., Heald, C. L., and Jimenez, J. L.: Evolution of Asian aerosols during transpacific transport in INTEX-B, Atmos. Chem. Phys., 9, 7257-7287, doi:10.5194/acp-9-7257-2009, 2009.

Fiore, A., Jacob, D. J., Liu, H., Yantosca, R. M., Fairlie, T. D., and Li, Q.: Variability in surface ozone background over the United States: Implications for air quality policy, J. Geophys. Res., 108(D24), 4787, doi:10.1029/2003JD003855, 2003.

Giglio, L., Descloitres, J., Justice, C. O., and Kaufman, Y. J.: An Enhanced Contextual Fire Detection Algorithm for MODIS, Remote Sens. Environ., 87, 273-282, 2003.

Huang, M., Carmichael, G. R., Adhikary, B., Spak, S. N., Kulkarni, S., Cheng, Y. F., Wei, C., Tang, Y., Parrish, D. D., Oltmans, S. J., D'Allura, A., Kaduwela, A., Cai, C., Weinheimer, A. J., Wong, M., Pierce, R. B., Al-Saadi, J. A., Streets, D. G., and Zhang, Q.: Impacts of transported background ozone on California air quality during the ARCTAS-CARB period - a multi-scale modeling study, Atmos. Chem. Phys., 10, 6947-6968, doi:10.5194/acp-10-6947-2010, 2010.

Huang, M., Carmichael, G. R., Kulkarni, S., Spak, S. N., Chai, T., Oltmans, S. J., Jaffe, D. A.,Streets, D. G., Kaduwela, A., Weinheimer, A. J., and Huey, G. L.: Source attribution at western U.S. coastal receptors and the impacts of coastal-inland transport of pollutants and local fires on surface air quality, J. Geophys. Res., under review, 2011.

IPCC: Contribution of Working Group I to the Fourth Assessment Report of the Intergovernmental Panel on Climate Change, Climate Change 2007: The Physical Science Basis, Cambridge, UK and New York, NY, USA, Cambridge University Press, 2007.

Jacob D. J., Horowitz L. W., Munger J. W., Heikes B. G., Dickerson R. R., Artz R. S., and Keene W. C.: Seasonal transition from $\mathrm{NO}_{\mathrm{x}}$ to hydrocarbon-limited conditions for ozone production over the eastern United States in September, J. Geophys. Res., 100, 93159324, 1995.

Jacob, D. J., Crawford, J. H., Maring, H., Clarke, A. D., Dibb, J. E., Emmons, L. K., Ferrare, R. A., Hostetler, C. A., Russell, P. B., Singh, H. B., Thompson, A. M., Shaw, G. E., McCauley, E., Pederson, J. R., and Fisher, J. A.: The Arctic Research of the Compositionof the Troposphere from Aircraft and Satellites (ARCTAS)mission: design, execution, and first results, Atmos. Chem. Phys., 10, 5191-5212, doi:10.5194/acp-10-5191-2010, 2010.

Koo, B., Chien, C.-Y.,Tonnesen, G., Morris, R., Johnson, J. Sakulyanontvittaya, T., Piyachaturawat, P., and Yarwood, G.: Natural emissions for regional modeling of background ozone and particulatematter and impacts on emissions control strategies, Atmos. Environ., 44, 2372-2382, 2010.

Lathiere, J., Hauglustaine, D. A., Friend, A. D., De NobletDucoudre, N., Viovy, N., and Folberth, G. A.: Impact of climate variability and land use changes on global biogenic volatile organic compound emissions, Atmos. Chem. Phys, 6, 2129-2146, 2006, doi:10.5194/acp-6-2129-2006, 2006.

Luecken, D. J., Phillips, S., Sarwar, G., and Jang, C.: Effects of using the CB05 vs. SAPRC99 vs. CB4 chemical mechanism on model predictions: Ozone and gas-phase photochemical precursorconcentrations, Atmos. Environ., 42, 5805-5820, 2008.

McNaughton, C. S., Thornhill, L., Clarke, A. D., Howell, S. G., Pinkerton, M., Anderson, B., Winstead, E., Hudgins, C., Maring, H., Dibb, J. E., and Scheuer, E.: Results from the DCinlet characterization experiment (DICE): Airborne versus surfacesampling of mineral dust and sea salt aerosols, Aerosol Sci. Technol., 40, 136-159, 2007.

Mesingera, F., DiMego, G., Kalnay, E., Mitchell, K., Shafran, P. C., Ebisuzaki, W., Jovic, D., Woollen, J., Rogers, E., Berbery, E. H., Ek, M. B., Fan, Y., Grumbine, R., Higgins, W., Li, H., Lin, Y., Manikin, G., Parrish, D., and Shi, W.: North American Regional Reanalysis. B. Am. Meteorol. Soc., 87(3), 343-360, doi:10.1175/BAMS-87-3-343, 2006.

Milford, J. B., Gao, D., Sillman, S., Blossey, P., and Russell, A. G.: Total reactive nitrogen $\left(\mathrm{NO}_{\mathrm{y}}\right)$ as an indicator of the sensitivity of ozone to reductions in hydrocarbon and $\mathrm{NO}_{\mathrm{x}}$ emissions, $\mathrm{J}$. Geophys. Res., 99, 3533-3542, 1994.

NASA: $\mathrm{OMI} \mathrm{O}_{3}$ column data source: ftp://toms.gsfc.nasa.gov/pub/ omi/data/ozone/Y2008/, 2008.

NCEP/NOAA: Real-time, global, sea surface temperature (RTG_SST) analysis data source: ftp://polar.ncep.noaa.gov/pub/ history/sst/, 2008.

NOAA: 2010 CalNex Science and Implementation Plan, http:// www.esrl.noaa.gov/csd/calnex/scienceplan.pdf, 2008

Pfister, G. G., Wiedinmyer, C., and Emmons, L. K.: Impacts of the fall 2007 Californiawildfires on surface ozone: Integrating local observations withglobal model simulations, Geophys. Res. Lett., 35, L19814, doi:10.1029/2008GL034747, 2008.

Sandu, A., Daescu, D. N., Carmichael, G. R., and Chai, T.:Adjoint sensitivityanalysis of regional air quality models. J. Comput. Phys., 204(1), 222-252, 2005.

Scheuer, E., Talbot, R. W., Dibb, J. E., Seid, G. K., deBell, L., and Lefer, G.: Seasonal distributions of fine aerosol sulfate in the North American Arctic Basin during TOPSE, J. Geophys. Res., 108, 8370, doi:doi:10.1029/2001JD001364, 2003.

Sillman, S.: The use of $\mathrm{NO}_{\mathrm{y}}, \mathrm{H}_{2} \mathrm{O}_{2}$, and $\mathrm{HNO}_{3}$ as indicators for 
ozone- $\mathrm{NO}_{\mathrm{x}}$-hydrocarbon sensitivity in urban locations, J. Geophys. Res., 100, 14175-14188, 1995.

Slusher, D. L., Huey, L. G., Tanner, D. J., Flocke, F. M., and Roberts, J. M.: A thermal dissociation-chemical ionization massspectrometry (TD-CIMS) technique for the simultaneous measurementof peroxyacyl nitrates and dinitrogenpentoxide, J. Geophys. Res., 109, D19315, doi:10.1029/2004JD004670, 2004.

Tang, Y., Carmichael, G. R., Horowitz, L. W., Uno, I., Woo, J.H., Streets, D. G., Dabdub, D., Kurata, G., Sandu, A., Allan, J., Atlas, E., Flocke, F., Huey, L. G., Jakoubek, R. O., Millet, D. B., Quinn, P. K., Roberts, J. M., Worsnop, D. R., Goldstein, A., Donnelly, S., Schauffler, S., Stroud, V., Johnson, K., Avery, M. A., Singh, H. B., and Apel, E. C.: Multiscale simulations of tropospheric chemistry in the eastern Pacific and on the U.S. West Coast during spring 2002, J. Geophys. Res., 109, D23S11, doi:10.1029/2004JD004513, 2004.

Viswanathan, S., Eria, L., Diunugala, N., Johnson, J., and McClean, C.: An analysis of effects of San Diego wildfire on ambient air quality, J. Air Waste Manage. Assoc., 56(1), 56-67, 2006.
Vutukuru, S. and Dabdub, D.: Modeling the effects of ship emissions on coastal air quality: A case study of southern California, Atmos. Environ., 42, 3751-3764, 2008.

Wang, H., Jacob, D. J., Sager, P. L., Streets, D. G., Park, R. J., and Gilliland, A. B., and van Donkelaar, A.: Surface ozone background in the United States: Canadianand Mexican pollution influences. Atmos. Environ., 43, 1310-1319, 2009.

Weinheimer, A. J., Walega, J. G., Ridley, B. A., Gary, B. L., Blake,D. R., Blake, N. J., Rowland, F. S., Sachse, G. W., Anderson, B. E., and Collins, J. E.: Meridional distributions of $\mathrm{NO}_{\mathrm{x}}$, $\mathrm{NO}_{\mathrm{y}}$, and other species in the lower stratosphere and upper troposphereduring AASE II, Geophys. Res. Lett., 21, 2583-2586, 1994.

WRF/Chem Version 3.1 User's Guide: http://ruc.noaa.gov/wrf/ WG11/Users_guide.pdf, 2009. 